PRACE GEOGRAFICZNE

zeszyt $161,2020,7-40$

doi: 10.4467/20833113PG.20.006.12548

Instytut Geografii i Gospodarki Przestrzennej UJ

Komisja Geograficzna, Polska Akademia Umiejętności

Wydawnictwo Uniwersytetu Jagiellońskiego

\title{
WPEYW DOŚWIADCZENIA \\ NA MOTYWY UPRAWIANIA NARCIARSTWA \\ NA PRZYKŁADZIE TATRZAŃSKICH OŚRODKÓW \\ NARCIARSKICH: KASPROWY WIERCH (POLSKA) \\ I TATRZAŃSKA ŁOMNICA (SŁOWACJA)
}

\author{
Joanna Hibner
}

\section{Impact of experience on the motives of skiers on the example of Tatra ski resorts: Kasprowy Wierch (Poland) and Tatrzańska Łomnica (Slovakia)}

\begin{abstract}
Both the motivation and the experience of tourists depend on psychological processes, being very individual for each person. They are closely related with each other and, also, they are affected by each other in many aspects. The aim of this article is to characterize the relationship between the motivation and the past mountain and ski experience of respondents from two Tatra ski resorts: Kasprowy Wierch (Poland) and Tatrzańska Łomnica (Slovakia). In order to gain information about the motivation and experience of tourists a survey using the PAPI technique was conducted during the winter seasons 2014/2015 and 2015/2016. A total of 404 questionnaires was collected (Kasprowy Wierch - 197; Tatrzańska Łomnica -207). The results confirm that tourists' motivation as well as their past mountain and ski experience are dependent on each other. Past experience and tourist motivation are both affected by other factors, including the type of activity or the frequency of visits. The research also shows that especially the past mountain experience affects many other variables including tourist motivation.
\end{abstract}

Keywords: ski tourism, Tatra Mountains, survey, tourists' experience, tourists' motives 
Zarys treści: Zarówno motywacje turystyczne, jak i doświadczenie turystyczne, są uzależnione m.in. od procesów psychologicznych zachodzących w każdym człowieku indywidualnie. Są one ze sobą ściśle związane pod wieloma aspektami i wzajemnie na siebie oddziałują. Celem niniejszego artykułu jest scharakteryzowanie wzajemnych zależności między motywacjami a wcześniejszymi doświadczeniami górskimi i narciarskimi respondentów z dwóch tatrzańskich ośrodków narciarskich: Kasprowy Wierch (Polska) i Tatrzańska Łomnica (Słowacja). W pracy zastosowano badania ankietowe na próbie łącznie 404 respondentów (Kasprowy Wierch - 197; Tatrzańska Łomnica -207). Badania ankietowe przeprowadzono, stosując technikę PAPI, czyli wywiad bezpośredni, w sezonie zimowym 2014/2015 i 2015/2016. Badania potwierdzają, że zarówno motywacje turystyczne, jak i wcześniejsze doświadczenia górskie i narciarskie są od siebie zależne. Zarówno wcześniejsze doświadczenia, jak i motywacje turystyczne są zależne od innych czynników, w tym m.in. od typu uprawianej aktywności czy też częstotliwości przyjazdów. $Z$ badań wynika, że przede wszystkim wcześniejsze doświadczenia górskie wpływają na inne zmienne, m.in. na motywacje turystyczne.

Stowa kluczowe: turystyka narciarska, Tatry, badania sondażowe, doświadczenie turystyczne, motywacje turystyczne

\section{Wprowadzenie}

Studia nad motywacjami turystycznymi należą do najtrudniejszych w psychologii (Faracik 2011). Wynika to z faktu, iż zarówno motywacje, jak i doświadczenie turystyczne są ściśle uzależnione od procesów psychologicznych zachodzących w każdym człowieku indywidualnie (Quan, Wang 2003). Według Larsena (2007) mimo obszernej literatury studia nad doświadczeniem turystycznym również należą do słabo rozpoznanych.

W teorii motywacji turystycznych istotną rolę odgrywają potrzeby i pragnienia definiowane jako pewien rodzaj niespełnienia, braku czegoś. Objawia się to w psychice ludzkiej jako motyw do działania lub też zaniechania pewnych działań (Faracik 2011; Fodness 1994; Kozioł 2012a). Według Murraya (1964, za: Snepenger i in. 2006) motyw jest wewnętrznym czynnikiem, który wpływa na zachowanie jednostki. W literaturze przedmiotu istnieje ponadto wiele definicji motywów i motywacji, np. Armstronga (2006, za: Kozioł 2012a), Rheinberga (2006, za: Kozioł 2012a) lub Łukaszewskiego (2000, za: Kozioł 2012a), Crompton i McKay (1997). Zadaniem teorii motywacji turystycznych jest zatem pomoc w wyjaśnieniu zachowań turystycznych, jak również w zaspokajaniu potrzeb i pragnień turystów (Gnoth 1997). Istnieje wiele prób klasyfikacji motywów turystycznych, m.in. klasyfikacje McIntosha i Goeldnera (1986, za: Kozioł 2012a), Middletona (1996, za: Kozioł 2012a), Bocheńskiej i Bujaka (1975, za: Faracik 2011), Przecławskiego (1996, za: Faracik 2011), lecz z uwagi na trudności interpretacyjne mają one głównie charakter teoretyczny. Zdebski (1979) dokonał klasyfikacji motywacji górskich, dzieląc je na: (1) motyw poznawczy - głód 
nowych doznań, wrażeń; (2) chęć zdobycia odznaczeń górskich; (3) potrzeba utrzymania/nawiązania więzi z innymi ludźmi; (4) potrzeba kontaktu emocjonalnego; (5) potrzeba wysiłku, ruchu, rywalizacji; (6) potrzeba prestiżu oraz (7) motyw ambicyjny. Winiarski (1991) dokonał natomiast klasyfikacji motywacji zachowań rekreacyjnych, wyróżniając motywację: (1) aktywnościową - potrzeba aktywności fizycznej; (2) katarktyczną - potrzeba odpoczynku od codzienności; (3) zdrowotną aktywność fizyczna jako metoda dbania o własne zdrowie; (4) emocjonalną - potrzeba przeżycia czegoś ekscytującego; (5) społeczną - potrzeba poznania nowych osób; (6) ambicjonalną - potrzeba podwyższenia własnej samooceny; (7) poznawczą potrzeba zdobycia nowych doświadczeń, umiejętności (Faracik 2011; Zdebski 2010). W oparciu o czynniki motywacyjne powstały również liczne typologie turystów (Cohen 1979; Loker-Murphy, Pierce 1995, za: Faracik 2011; Pierce 1982, za: Faracik 2011; Wickens 2002; Winiarski 1991, za: Faracik 2011; Przecławski 1996; Stankey 1973). Ciekawą koncepcję dotyczącą motywacji turystycznych przedstawił również Dann (1977, za: Snepenger i in. 2006), dzieląc czynniki motywacyjne na dwie kategorie: czynniki typu push - skłaniające ludzi do podjęcia aktywności turystycznej, oraz czynniki typu pull - przyciągające turystów do konkretnych destynacji (Bansal, Eiselt 2004; Crompton, McKay 1997; Kozioł 2012a, 2012b; Snepenger i in. 2006).

Motywacje turystyczne i doświadczenie są ze sobą ściśle związane pod wieloma względami (Niezgoda 2013a, 2013b; Quinlan Cutler, Carmichael 2010; Snepenger i in. 2006). Przede wszystkim samo doświadczenie w aspekcie emocjonalnym stanowi istotne źródło motywacji do wyjazdów turystycznych (Niezgoda 2013a). Potrzeby przeżycia czegoś ekscytującego, nowych doświadczeń, wrażeń, są uwidocznione chociażby w klasyfikacjach Zdebskiego (1979) i Winiarskiego (1991, za: Faracik 2011). Co więcej, motywacje i potrzeby turystyczne są bardzo indywidualne i zmieniają się, np. wraz z wcześniejszymi doświadczeniami (Niezgoda 2013a, 2013b).

Termin „doświadczenie” posiada wiele znaczeń. Słownik Języka Polskiego PWN podaje aż cztery. Jedno z nich odnosi się do ogółu informacji i umiejętności zdobytych przez człowieka na podstawie własnych obserwacji i przeżyć (Stasiak 2016). Podobną definicję podaje także słownik Merriam-Webster (2020). Ponadto w literaturze przedmiotu istnieje wiele definicji „doświadczenia”, jak również „doświadczenia turystycznego” (Andersson 2007; Dziewanowska, Kacprzak 2016; Mossberg 2007; Nowacki, Kruczek 2019; Oh i in. 2007; Uriely 2005; Walls i in. 2011). Według Mossberg (2007) doświadczenie to nie tylko nabyte umiejętności, ale przede wszystkim połączenie wielu czynników angażujących człowieka emocjonalnie, fizycznie, intelektualnie i duchowo.

Pod koniec lat 90. XX w. Pine i Gilmore (1998) ogłosili nową koncepcję ekonomii, tzw. ekonomię doświadczeń ( $\mathrm{z}$ ang. experience economy). Według autorów po gospodarce 
opartej na rolnictwie, produkcji oraz usługach nastąpił czas gospodarki opartej na doświadczeniach, przeżyciach, doznaniach (Dziewanowska, Kacprzak 2016; Neuhofer i in. 2012; Nowacki, Kruczek 2019; Pine, Gilmore 1998; Stasiak 2013, 2015, 2016). Ekonomia doświadczeń ma swoje zastosowanie w branży turystycznej, gdyż turystyka oferuje nie tylko usługi, ale przede wszystkim wrażenia, doznania, przeżycia (Niezgoda 2013a, 2013b; Stasiak 2016). Na doświadczenia turystyczne wpływa wiele elementów, m.in. motywacje, oczekiwania, wiedza, satysfakcja, pamięć, percepcja czy emocje (Quinlan Cutler, Carmichael 2010; Walls i in. 2011).

Ciekawą koncepcję doświadczenia turystycznego przedstawił Hall (2003, za: Mika 2014). Według niego doświadczenie turystyczne to niejako zbiór doznań, wrażeń, przeżyć - w sferze zarówno emocjonalnej, jak i fizycznej - które powstaje, gdy potrzeby i oczekiwania turystów „spotykają” się z rzeczywistym produktem, usługą. Co więcej, według Halla (2003) tak rozumiane doświadczenia turystyczne wpływają na podejmowane przez człowieka decyzje dotyczące miejsca wypoczynku, rodzaju turystyki itd. (Hall 2003, za: Mika 2014).

Turystyka narciarska uważana jest za drugą, po turystyce pieszej, najpopularniejszą formę turystyki uprawianej na obszarach górskich (Kurek 2004). Według istniejących statystyk Tatrzański Park Narodowy po stronie polskiej (TPN) odwiedza rocznie około 4 mln turystów, z czego 14\% stanowią osoby odwiedzające park zimą (TPN statystyki 2019). Z danych otrzymanych od operatora kolejek po słowackiej stronie Tatr wynika, iż około 45\% wszystkich biletów sprzedanych na przejazdy kolejkami w ośrodku Tatrzańska Łomnica to bilety sprzedane w okresie zimowym, głównie dla narciarzy. Tak rosnące znaczenie tej formy turystyki sprawia, iż stanowi ona duże wyzwanie dla osób zarządzających obszarami chronionymi (Eagles i in. 2002; Krzesiwo 2015). Poznanie potrzeb i motywacji turystów wpływa na lepszą komunikację między osobami zarządzającymi obszarami chronionymi a turystami (Cessford, Muhar 2003; Konu, Kajala 2012).

\section{Operacjonalizacja pojęć}

Jak wspomniano we wprowadzeniu, pojęcie doświadczenia turystycznego ma wiele znaczeń. Niniejsza praca zostanie poświęcona wcześniejszym doświadczeniom turystycznym, rozumianym zgodnie z koncepcją Halla (2003, za: Mika 2014) jako zbiór przeszłych doznań emocjonalnych i fizycznych, a także ich relacji z innymi czynnikami. W tej pracy wcześniejsze doświadczenie turystyczne zostało podzielone na wcześniejsze doświadczenia narciarskie oraz wcześniejsze doświadczenia górskie. Wcześniejsze doświadczenia narciarskie rozumiane są tu jako suma doświadczeń (fizycznych i emocjonalnych) wynikających z korzystania z różnych obiektów narciarskich, natomiast wcześniejsze doświadczenia górskie jako suma 
doświadczeń, wrażeń wynikających z uprawiania różnych form turystyki górskiej w różnych porach roku.

\section{Cel pracy}

Celem niniejszego artykułu jest scharakteryzowanie wzajemnych zależności między motywacjami respondentów a ich wcześniejszymi doświadczeniami turystycznymi. Realizację postawionego celu poprzedzono zidentyfikowaniem potrzeb i motywacji turystów, dotyczących zarówno uprawiania narciarstwa, jak i wyboru konkretnych ośrodków narciarskich.

\section{Obszar badań}

Badania prowadzono w dwóch ośrodkach narciarskich: Kasprowy Wierch (Polska) i Tatrzańska Łomnica (Słowacja), znajdujących się na terenie Tatr - najwyższego karpackiego łańcucha górskiego, położonego na pograniczu Polski i Słowacji. Od połowy XX w. obszar ten w całości stanowi park narodowy (polski Tatrzański Park Narodowy, TPN, powstał w 1954 r., a słowacki Tatranský Národný Park, TANAP, w 1949 r.; TANAP 2019; TPN 2019). Działanie obydwu ośrodków narciarskich opiera się na powstałych w latach 30. XX w. kolejkach linowych. Po stronie polskiej jest to kolejka z Kuźnic (Zakopane) na Kasprowy Wierch (1949 m n.p.m.) ze stacją pośrednią Myślenickie Turnie. Oddano ją do użytku w 1936 r. W latach 2006 i 2007 została poddana gruntownej modernizacji, co poskutkowało zwiększeniem przepustowości do 360 osób na godzinę w sezonie zimowym. Po stronie słowackiej jest to kolejka z Tatrzańskiej Łomnicy na Łomnicę (2632 m n.p.m.) ze stacjami pośrednimi Štart oraz Łomnicki Staw. Pierwsza część kolejki została oddana do użytku w 1938 r., a kolejna, już na sam szczyt Łomnicy, w 1940 r. Obu kolejkom towarzyszą dziś dodatkowe kolejki krzesełkowe, które powiększają teren uprawniania narciarstwa. Ośrodek przy Kasprowym Wierchu obsługiwany jest przez kolejkę linową i dwie kolejki krzesełkowe. Ośrodek Tatrzańska Łomnica - przez dwie kolejki gondolowe, cztery kolejki krzesełkowe oraz dwa mniejsze wyciągi dla dzieci. Najwyżej usytuowana jest 2-osobowa kolejka krzesełkowa z Łomnickiego Stawu (1751 m n.p.m.) na Łomnicką Przełęcz (2190 m n.p.m.) (Laszczyk i in. 2007; PKL kolejki 2019; Skawiński 2005; Vysoke Tatry kolejki 2019). Ośrodek przy Kasprowym Wierchu oferuje narciarzom dwie trasy narciarskie w Kotłach: Goryczkowym i Gąsienicowym, określane jako trasy trudne i znakowane na czarno; nartostradę przez Dolinę Gąsienicową do Kuźnic, określaną jako łatwą; a ponadto szlaki narciarskie w rejonie Doliny Gąsienicowej oraz w rejonie Doliny Goryczkowej i Hali Kondratowej 
(tab. 1; Kasprowy Wierch trasy narciarskie 2019). Ośrodek Tatrzańska Łomnica dysponuje znacznie szerszą i dostosowaną do różnego poziomu ofertą dla ruchu narciarskiego. W ośrodku znajdują się dwie trasy o dużym stopniu trudności. Są to trasa czarna z Łomnickiej Przełęczy oraz strefa free ridu, tzw. Francúzska mulda. Ponadto ośrodek dysponuje czterema trasami o średnim stopniu trudności z Łomnickiego Stawu do Tatrzańskiej Łomnicy (Esíčka, Generál, Čučoriedky vỳchod i Čučoriedky zapad). W ośrodku znajdują się również trasy łatwe ze Štartu i Bukovej Hory (tab. 1; Vysoke Tatry trasy narciarskie 2019).

Tab. 1. Trasy narciarskie w ośrodkach Kasprowy Wierch i Tatrzańska Łomnica Table 1. Ski routes in the Kasprowy Wierch and the Tatrzańska Łomnica ski resorts

\begin{tabular}{|c|c|c|}
\hline \multicolumn{3}{|c|}{ KASPROWY WIERCH / KASPROWY WIERCH SKI RESORT } \\
\hline $\begin{array}{c}\text { Nazwa trasy } \\
\text { Name of the ski route }\end{array}$ & $\begin{array}{l}\text { Stopień trudności trasy/kolor } \\
\text { Difficulty of the route/colour of the ski route }\end{array}$ & $\begin{array}{l}\text { Długość trasy }(\mathrm{m}) \\
\text { Length of the route }(\mathrm{m})\end{array}$ \\
\hline Gąsienicowa & trudna/czarna & 1200 \\
\hline Goryczkowa & trudna/czarna & 1770 \\
\hline $\begin{array}{c}\text { Nartostrada } \\
\text { Goryczkowa - Kuźnice }\end{array}$ & łatwa/niebieska & 3500 \\
\hline Hala Gąsienicowa - szlaki narciarskie & - & 8500 \\
\hline Hala Kondratowa - szlaki narciarskie & - & - \\
\hline \multicolumn{3}{|c|}{ TATRZAŃSKA ŁOMNICA / TATRZAŃSKA ŁOMNICA SKI RESORT } \\
\hline $\begin{array}{l}\text { Nazwa trasy } \\
\text { Name of the ski route }\end{array}$ & $\begin{array}{l}\text { Stopień trudności trasy/kolor } \\
\text { Difficulty of the route/colour of the ski route }\end{array}$ & $\begin{array}{l}\text { Długość trasy }(\mathrm{m}) \\
\text { Length of the route }(\mathrm{m})\end{array}$ \\
\hline Łomnicka Przełęcz & trudna/czarna & 1240 \\
\hline Strefa Free Ride Francúzska Mulda & trudna & - \\
\hline Esička & średnia/czerwona & 1300 \\
\hline Generál & średnia/czerwona & 1350 \\
\hline Čučoriedky vỳchod & średnia/czerwona & 960 \\
\hline Čučoriedky zapad & średnia/czerwona & 880 \\
\hline Buková hora vỳchod & średnia/czerwona & 700 \\
\hline Javorova cesta I \& II & łatwa/niebieska & $450 / 250$ \\
\hline Grand SInečna & łatwa/niebieska & 1100 \\
\hline Štart zapad & łatwa/niebieska & 2000 \\
\hline Štart vỳchod & łatwa/niebieska & 850 \\
\hline
\end{tabular}

Źródto: Hibner 2018; Kasprowy Wierch trasy narciarskie 2019; Vysoke Tatry trasy narciarskie 2019. Source: Hibner 2018; Kasprowy Wierch trasy narciarskie 2019; Vysoke Tatry trasy narciarskie 2019. 


\section{Metodyka badań}

Głównym narzędziem badawczym wykorzystanym do celów niniejszego opracowania była ankieta. Badania ankietowe przeprowadzono, stosując technikę PAPI (Paper \& Pen Personal Interview), czyli technikę wywiadu bezpośredniego w terenie. Dobór próby badawczej miał charakter nielosowy, przypadkowy, zwany również okolicznościowym. Był on podyktowany dostępnością respondentów w warunkach górskich. Reprezentatywność próby została zapewniona w zakresie profilu społeczno-demograficznego respondentów - narciarzy korzystających ze stacji narciarskich Kaprowy Wierch i Tatrzańska Łomnica. Zbliżoną metodologią, wykorzystującą podobną metodę badawczą i sposób doboru próby, posługiwali się m.in. Švajdy i in. (2018) oraz Hoholíková i Šturcel (2005). Uzyskane wyniki dotyczące profilu społeczno-demograficznego respondentów we wspomnianych badaniach są podobne do wyników badań własnych autorki. Badania ankietowe prowadzono w sezonie zimowym 2014/2015 i 2015/2016 przez łącznie 14 dni, głównie w trakcie weekendów w rejonach górnych stacji kolejek linowych, w obu ośrodkach narciarskich. Do analizy wzięto pod uwagę łącznie 404 ankiety (Kasprowy Wierch - 197, Tatrzańska Łomnica - 207). Ankieta podzielona była na 4 sekcje tematyczne: I - informacje ogólne nt. wycieczki, II - motywacje, III - opinie, IV - doświadczenie i bezpieczeństwo oraz metryczka. Do celów niniejszego opracowania wykorzystano informację z sekcji I, II oraz IV.

Respondentów zapytano o częstotliwość przyjazdów do badanych ośrodków narciarskich oraz rodzaj aktywności fizycznej uprawianej na obszarze badań. Ponadto poproszono ich o wskazanie głównego czynnika, z którego powodu wybrali konkretny ośrodek narciarski, oraz o wskazanie głównego motywu ich pobytu w górach/ uprawiania turystyki narciarskiej w górach. W ostatnim przypadku w doborze czynników motywacyjnych wykorzystano opracowanie Konu i Kajala (2012) oraz opracowanie dotyczące motywacji zachowań rekreacyjnych Winiarskiego (1991, za: Zdebski 2010). Respondenci w pytaniach dotyczących motywacji najpierw mieli możliwość wielokrotnego wyboru odpowiedzi, a następnie zostali poproszeni o podkreślenie, spośród wybranych przez siebie czynników motywacyjnych, jednego, najważniejszego czynnika motywacyjnego - zwanego dalej głównym motywem uprawiania turystyki narciarskiej / wyjazdu narciarskiego. Respondentom zaproponowano 22 czynniki motywacyjne do wyboru i dodatkowo możliwość własnego wpisu. Uzyskane odpowiedzi w zakresie czynników zaklasyfikowano do kilku kategorii. Wcześniejsze doświadczenia narciarskie respondentów określono na podstawie pytania o pobyt w innych ośrodkach narciarskich (krajowych lub zagranicznych). Respondentów zapytano o to, czy bywali także w innych ośrodkach narciarskich, oraz jakie to były ośrodki (krajowe lub zagraniczne). $\mathrm{Na}$ tej podstawie odpowiedzi respondentów zaklasyfikowano do 4 kategorii: pobyt 
tylko we wskazanym ośrodku, pobyt w innych krajowych ośrodkach, pobyt w zagranicznych ośrodkach, pobyt zarówno w innych krajowych, jak i zagranicznych ośrodkach narciarskich. Zatem, wedle założeń autorki, osoby korzystające z różnych obiektów narciarskich w różnych ośrodkach, w różnych krajach będą w niniejszej pracy określane jako osoby posiadające „,bogatsze” doświadczenia narciarskie w stosunku do osób korzystających tylko z jednego wskazanego ośrodka. Wcześniejsze doświadczenia górskie respondentów określono na podstawie liczby innych aktywności uprawianych do tej pory przez ankietowanych w górach. Respondentów zapytano o to, jakie aktywności uprawiali do tej pory w górach i w jakiej porze roku, tj. spacery dolinami (zima/lato), wycieczki powyżej dolin (zima/lato), wycieczki w wyższe partie gór (zima/lato), przejścia tras trudnych technicznie (zima/lato), wspinaczka skałkowa, wspinaczka górska, narciarstwo/ snowboarding, skitouring, odwiedzanie turystyczne jaskiń, taternictwo jaskiniowe.

Następnie podsumowano liczbę oraz rodzaje aktywności górskich, które poszczególni respondenci uprawiali, i zaklasyfikowano tę zmienną jako doświadczenia górskie - liczba uprawianych aktywności górskich. Wedle założeń autorki osoby, które miały sposobność uprawiana większej liczby różnych form turystyki górskiej, określane będą w niniejszej pracy jako osoby posiadające „bogatsze” doświadczenia górskie. Zawarta w ankiecie metryczka pozwoliła natomiast na scharakteryzowanie użytkowników tras narciarskich pod kątem społeczno-demograficznym (Babbie 2003; Konu, Kajala 2012; Kurek 2011). Odpowiedzi respondentów zostały zakodowane w bazie danych SPSS Statistics, a następnie poddane analizie statystycznej. Celem sprawdzenia zależności pomiędzy poszczególnymi zmiennymi (tj. doświadczenia górskie, doświadczenia narciarskie, główny motyw uprawiana turystyki narciarskiej, główny czynnik wyboru konkretnego ośrodka narciarskiego, częstotliwość przyjazdów, rodzaj uprawianej aktywności podczas pobytu w ośrodkach narciarskich oraz wiek i płeć respondentów) zastosowano testy statystyczne nieparametryczne, tj. test $\mathrm{Chi}^{2}$ Pearsona, test Kruskala-Wallisa, test U Manna-Whitneya oraz test tau-b Kendalla. W pracy zastosowano testy nieparametryczne z uwagi na charakter i liczebność próby. Zdecydowano o zastosowaniu kilku rodzajów testów, biorąc pod uwagę charakter zmiennych analizowanych. Jako granicę istotności statystycznej przyjęto poziom $\mathrm{p}=0,05$. 


\section{Wyniki}

\section{Charakterystyka badanej grupy}

Grupę respondentów stanowiły zarówno narciarki (42\%), jak i narciarze (58\%). Wśród respondentów dominowały osoby młode, przede wszystkim w grupie wiekowej od 25. do 34. roku życia (33\%), oraz nieco starsze, w przedziale wiekowym od 35. do 44. roku życia (25\%). Zaobserwowano ponadto, iż odsetek osób po 50. roku życia był niewielki. Odnotowano także niewielki odsetek osób już pełnoletnich, ale jeszcze bardzo młodych, w przedziale wiekowym od 18. do 24. roku życia (8\%; tab. 2). Zdecydowana większość respondentów posiadała wykształcenie wyższe $(72 \%)$. Spory odsetek w badanej grupie stanowiły także osoby mające wykształcenie średnie (22\%; tab. 2). Respondenci w badanych ośrodkach narciarskich w zdecydowanej większości uprawiali narciarstwo zjazdowe (74\%). Snowboarding i skitouring, jako sporty zimowe, były zdecydowanie rzadziej reprezentowane (tab. 3).

Tab. 2. Profil społeczno-demograficzny respondentów

Table 2. Socio-demographic profile of respondents

\begin{tabular}{|c|c|c|c|c|c|}
\hline Płeć / Gender & $(\%)$ & Wiek / Age & $(\%)$ & $\begin{array}{c}\text { Wykształcenie } \\
\text { Level of education }\end{array}$ & $(\%)$ \\
\hline kobieta / female & 42 & $\begin{array}{c}\text { poniżej } 18 \\
\text { less than } 18\end{array}$ & 4 & $\begin{array}{l}\text { podstawowe } \\
\text { primary }\end{array}$ & 2 \\
\hline mężczyzna / male & 58 & $18-24$ & 8 & $\begin{array}{l}\text { gimnazjalne } \\
\text { lower secondary }\end{array}$ & 1 \\
\hline \multirow[t]{6}{*}{ razem / total } & 100 & $25-34$ & 33 & $\begin{array}{l}\text { zawodowe } \\
\text { vocational }\end{array}$ & 3 \\
\hline & & $35-44$ & 25 & $\begin{array}{l}\text { średnie } \\
\text { secondary }\end{array}$ & 22 \\
\hline & & $45-54$ & 20 & wyższe / higher & 72 \\
\hline & & $55-64$ & 8 & razem / total & 100 \\
\hline & & $\begin{array}{l}\text { powyżej } 64 \\
64 \text { and above }\end{array}$ & 3 & & \\
\hline & & razem / total & 100 & & \\
\hline
\end{tabular}

Źródto: na podstawie Hibner 2018.

Source: based on Hibner 2018. 
Tab. 3. Rodzaj aktywności fizycznej uprawianej przez respondentów w badanych ośrodkach narciarskich

Table 3. Type of physical activity conducted by respondents in both ski resorts

\begin{tabular}{|l|c|}
\hline \multicolumn{1}{|c|}{ Rodzaj aktywności / Type of the activity } & Odsetek odpowiedzi (\%) / Percentage of responses (\%) \\
\hline Narciarstwo zjazdowe / Skiing & 74 \\
\hline Snowboarding / Snowboarding & 14 \\
\hline Skitouring / Skitouring & 12 \\
\hline Razem / Total & 100 \\
\hline
\end{tabular}

Źródto: na podstawie Hibner 2018.

Source: based on Hibner 2018.

\section{Doświadczenia i motywacje respondentów}

Z przeprowadzonych badań wynika, iż respondenci odwiedzają wskazane ośrodki narciarskie regularnie: kilka razy w sezonie (38\%) lub raz w sezonie (21\%). Ponadto, istotny odsetek stanowili respondenci, którzy po raz pierwszy przyjechali do wspomnianych ośrodków (24\%; tab. 4.). Ankietowani, którzy odwiedzili Kasprowy Wierch po raz pierwszy, stanowili $21 \%$ ogółu. Natomiast respondentów, którzy po raz pierwszy jeździli na nartach w ośrodku Tatrzańska Łomnica, było $27 \%$.

Tab. 4. Częstotliwość przyjazdów do badanych ośrodków narciarskich Table 4. Frequency of visits in both ski resorts

\begin{tabular}{|l|c|}
\hline Częstotliwość przyjazdów / Frequency of visits & Odsetek odpowiedzi (\%) / Percentage of responses (\%) \\
\hline Jestem pierwszy raz / It's my first time ... & 24 \\
\hline Raz na jakiś czas bardzo rzadko / Very rarely & 11 \\
\hline Średnio co drugi sezon / Every other season & 6 \\
\hline Raz w sezonie / Once per season & 21 \\
\hline Kilka razy w sezonie / Several times per season & 38 \\
\hline Razem / Total & 100 \\
\hline
\end{tabular}

Źródto: na podstawie Hibner 2018.

Source: based on Hibner 2018. 
Wedle przeprowadzonych badań respondenci bardzo często korzystają z różnych ośrodków narciarskich. Ponad połowa z nich (52\%) bywała w innych, zarówno krajowych, jak i zagranicznych ośrodkach. Ponadto, 21\% badanych to osoby, które odwiedzają wyłącznie zagraniczne ośrodki narciarskie - przede wszystkim alpejskie. Pozostałe destynacje często wybierane przez respondentów z obu obszarów badawczych to ośrodki narciarskie w: Niemczech, Czechach, Rosji, krajach skandynawskich oraz USA i Argentynie. Odnotowano także, iż około $1 / 4$ ankietowanych korzysta wyłącznie z krajowych ośrodków narciarskich (polskich i słowackich; ryc. 1) ${ }^{1}$.

Na podstawie testu Chi ${ }^{2}$ wskazano zależność zmiennej wcæeśniejsæe doświadcæenia narciarskie od zmiennej obszar badań. W ośrodku na Kasprowym Wierchu stwierdzono znaczną przewagę ankietowanych, którzy bywają nie tylko w polskich, ale również zagranicznych ośrodkach narciarskich (60\%). W rejonie ośrodka Tatrzańska Łomnica odnotowano mniejszy odsetek osób, które odwiedzają zarówno krajowe,

Ryc. 1. Wcześniejsze doświadczenia narciarskie - czy respondent korzystał w swoim życiu z innych ośrodków narciarskich i jakie to były ośrodki?

Fig. 1. Past ski experience - whether respondent has visited other ski resorts during his life and which?

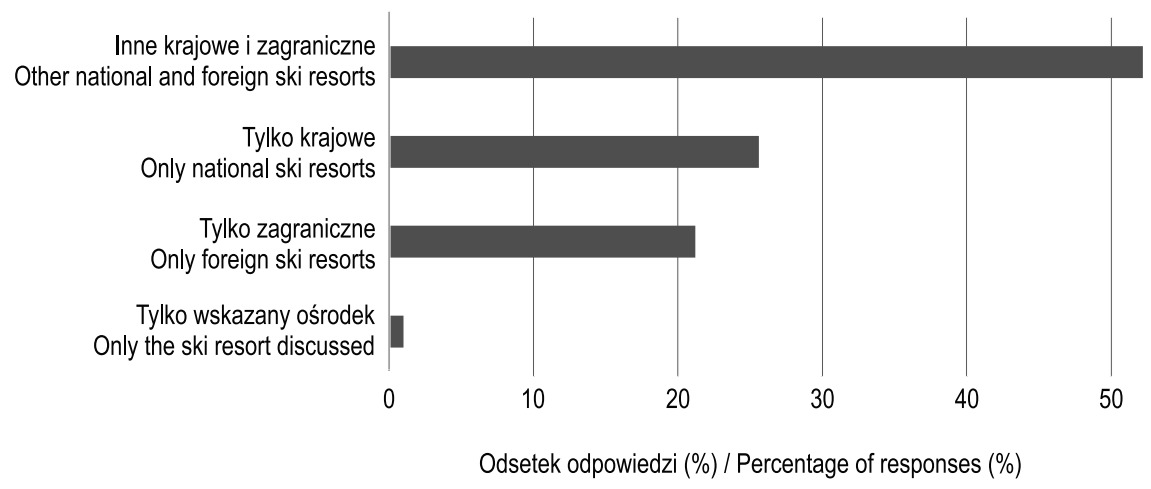

Źródto: na podstawie Hibner 2018.

Source: based on Hibner 2018.

${ }^{1} \mathrm{Z}$ danych autorki wynika, że ok. $21 \%$ respondentów, którzy przyjechali do ośrodka Tatrzańska Łomnica, stanowili Polacy. Nie ma natomiast takich danych odnośnie do całego Tatrzańskiego Parku Narodowego po stronie słowackiej, ponieważ TANAP nie prowadzi statystyk dotyczących ani liczby odwiedzin, ani narodowości odwiedzających. 
jak i zagraniczne ośrodki narciarskie. Natomiast w rejonie Tatrzańskiej Łomnicy zaobserwowano większy niż w rejonie Kasprowego Wierchu odsetek osób korzystających wyłącznie z krajowych ośrodków narciarskich (tab. 5). 66\%

Tab. 5. Wcześniejsze doświadczenia narciarskie respondentów w zależności od obszaru badań Table 5. Past ski experience analysed in terms of research area

\begin{tabular}{|c|c|c|c|c|}
\hline \multirow{2}{*}{$\begin{array}{l}\text { Pobyt w innych ośrodkach narciarskich } \\
\text { w ciągu życia } \\
\text { Stay in other ski resorts in the lifetime }\end{array}$} & \multicolumn{2}{|c|}{$\begin{array}{c}\text { Odsetek odpowiedzi (\%) } \\
\text { Percentage of responses (\%) }\end{array}$} & \multicolumn{2}{|r|}{ Test $\mathrm{Chi}^{2}$} \\
\hline & $\begin{array}{l}\text { Kasprowy } \\
\text { Wierch }\end{array}$ & Tatrzańska Łomnica & $\begin{array}{l}\text { wartość } \\
\text { value }\end{array}$ & $\begin{array}{l}\text { istotność asymptotyczna } \\
\text { (dwustronna) } \\
\text { asymp. Sig 2-sided }\end{array}$ \\
\hline $\begin{array}{l}\text { Tylko wskazany ośrodek } \\
\text { Only the ski resort discussed }\end{array}$ & 1 & 1 & \multirow{5}{*}{10,508} & \multirow{5}{*}{0,015} \\
\hline $\begin{array}{l}\text { Tylko ośrodki krajowe } \\
\text { Only national ski resorts }\end{array}$ & 22 & 29 & & \\
\hline $\begin{array}{l}\text { Tylko ośrodki zagraniczne } \\
\text { Only foreign ski resorts }\end{array}$ & 17 & 25 & & \\
\hline $\begin{array}{l}\text { Inne ośrodki krajowe i zagraniczne } \\
\text { Other national and foreign ski resorts }\end{array}$ & 60 & 45 & & \\
\hline Razem / Total & 100 & 100 & & \\
\hline
\end{tabular}

Źródto: na podstawie Hibner 2018.

Source: based on Hibner 2018.

Istotne statystycznie różnice odnotowano ponadto pomiędzy zmienną wcæéniejše doświadčenia narciarskie a częstotliwością przyjazdów do badanych ośrodków. $Z$ danych tych wynika, że wraz ze wzrostem częstotliwości przyjazdów do wskazanych ośrodków narciarskich spada odsetek osób korzystających zarówno z krajowych, jak i z zagranicznych ośrodków narciarskich. Natomiast rośnie odsetek osób korzystających wyłącznie z krajowych ośrodków. Dla przykładu: wśród osób rzadko odwiedzających badane ośrodki odnotowano aż 66\% tych, którzy bywają zarówno w krajowych, jak i zagranicznych ośrodkach narciarskich. Natomiast wśród respondentów odwiedzających te ośrodki często (kilka razy w sezonie) odsetek ten wynosi już tylko $50 \%$. Analogicznie, wśród ankietowanych rzadko odwiedzających badane ośrodki odnotowano tylko $18 \%$ udział tych bywających wyłącznie w krajowych ośrodkach narciarskich, ale już w grupie osób odwiedzających wskazane ośrodki często odsetek ten wzrastał do 30\%. Wyjątek stanowiły tu osoby, które po raz pierwszy przyjechały do badanych ośrodków w celu uprawiania sportów zimowych (tab. 6). Nie odnotowano istotnych statystycznie zależności między zmienną wcæeśniejsze 
Tab. 6. Wcześniejsze doświadczenia narciarskie respondentów a częstotliwość przyjazdów do badanych ośrodków narciarskich

Table 6. Past ski experience analysed in terms of frequency of visits

\begin{tabular}{|c|c|c|c|c|c|c|c|}
\hline \multirow{2}{*}{$\begin{array}{l}\text { Pobyt w innych ośrodkach } \\
\text { narciarskich w ciągu życia } \\
\text { Stay in other ski resorts in } \\
\text { the lifetime }\end{array}$} & \multicolumn{5}{|c|}{$\begin{array}{c}\text { Częstotliwość przyjazdów do badanych ośrodków } \\
\text { narciarskich (\%) } \\
\text { Frequency of visits in both ski resorts (\%) }\end{array}$} & \multicolumn{2}{|c|}{ Test Chi } \\
\hline & $\begin{array}{c}\text { pierwszy raz } \\
\text { it's my first } \\
\text { time }\end{array}$ & $\begin{array}{l}\text { bardzo } \\
\text { rzadko } \\
\text { very } \\
\text { rarely }\end{array}$ & \begin{tabular}{|} 
co drugi \\
sezon \\
every other \\
season
\end{tabular} & $\begin{array}{c}\text { raz } \\
\text { w sezonie } \\
\text { once per } \\
\text { season }\end{array}$ & $\begin{array}{l}\text { kilka razy } \\
\text { w sezonie } \\
\text { several } \\
\text { times per } \\
\text { season }\end{array}$ & $\begin{array}{l}\text { wartość } \\
\text { value }\end{array}$ & \begin{tabular}{|c|} 
istotność \\
asymptotyczna \\
(dwustronna) \\
asymp. Sig \\
2-sided
\end{tabular} \\
\hline $\begin{array}{l}\text { Tylko wskazany ośrodek } \\
\text { Only the ski resort discussed }\end{array}$ & 0 & 5 & 5 & 0 & 1 & \multirow{5}{*}{21,519} & \multirow{5}{*}{0,043} \\
\hline $\begin{array}{l}\text { Tylko ośrodki krajowe } \\
\text { Only national ski resorts }\end{array}$ & 24 & 18 & 24 & 26 & 30 & & \\
\hline $\begin{array}{l}\text { Tylko ośrodki zagraniczne } \\
\text { Only foreign ski resorts }\end{array}$ & 31 & 11 & 19 & 19 & 19 & & \\
\hline $\begin{array}{l}\text { Inne ośrodki krajowe } \\
\text { i zagraniczne } \\
\text { Other national and foreign } \\
\text { ski resorts }\end{array}$ & 45 & 66 & 52 & 55 & 50 & & \\
\hline Razem / Total & 100 & 100 & 100 & 100 & 100 & & \\
\hline
\end{tabular}

Źródto: na podstawie Hibner 2018.

Source: based on Hibner 2018.

doświadczenia narciarskie a zmiennymi o charakterze społeczno-demograficznym (wiek, płeć), zmiennymi dotyczącymi motywacji (motyw wyjazdu, czynnik wyboru wskazanego ośrodka), czy też zmienną określającą formy uprawianej aktywności.

Główną formą aktywności uprawianą przez respondentów w górach (nie tylko na obszarze badań) jest przede wszystkim narciarstwo zjazdowe/snowboarding (97\%), blisko $30 \%$ uprawia oprócz tego skitouring. Ponadto ok. $80 \%$ respondentów w lecie spacerowało w obrębie dolin górskich. Więcej niż 50\% respondentów deklarowało, iż w sezonie letnim wybierało się na wycieczki powyżej dolin, jak również w wyższe partie gór, a zimą spacerowało dolinami górskimi. Ponad $40 \%$ badanych odwiedziło także udostępnione dla turystów jaskinie górskie, a w okresie letnim przeszło bardziej wymagające trasy górskie (np. Orla Perć - Polska; Prielom - Słowacja). Blisko $40 \%$ deklarowało, iż w sezonie zimowym wybrało się na wycieczki powyżej dolin, a ponad $20 \%$ przeszło w sezonie zimowym szlaki w wyższych partiach gór. Wspinaczka skałkowa i górska, jak również przejście trudniejszych tras górskich w warunkach zimowych to aktywności uprawiane przez nieco ponad $10 \%$ badanych. Jedynie $3 \%$ respondentów to osoby uprawiające także taternictwo jaskiniowe (ryc. 2). 


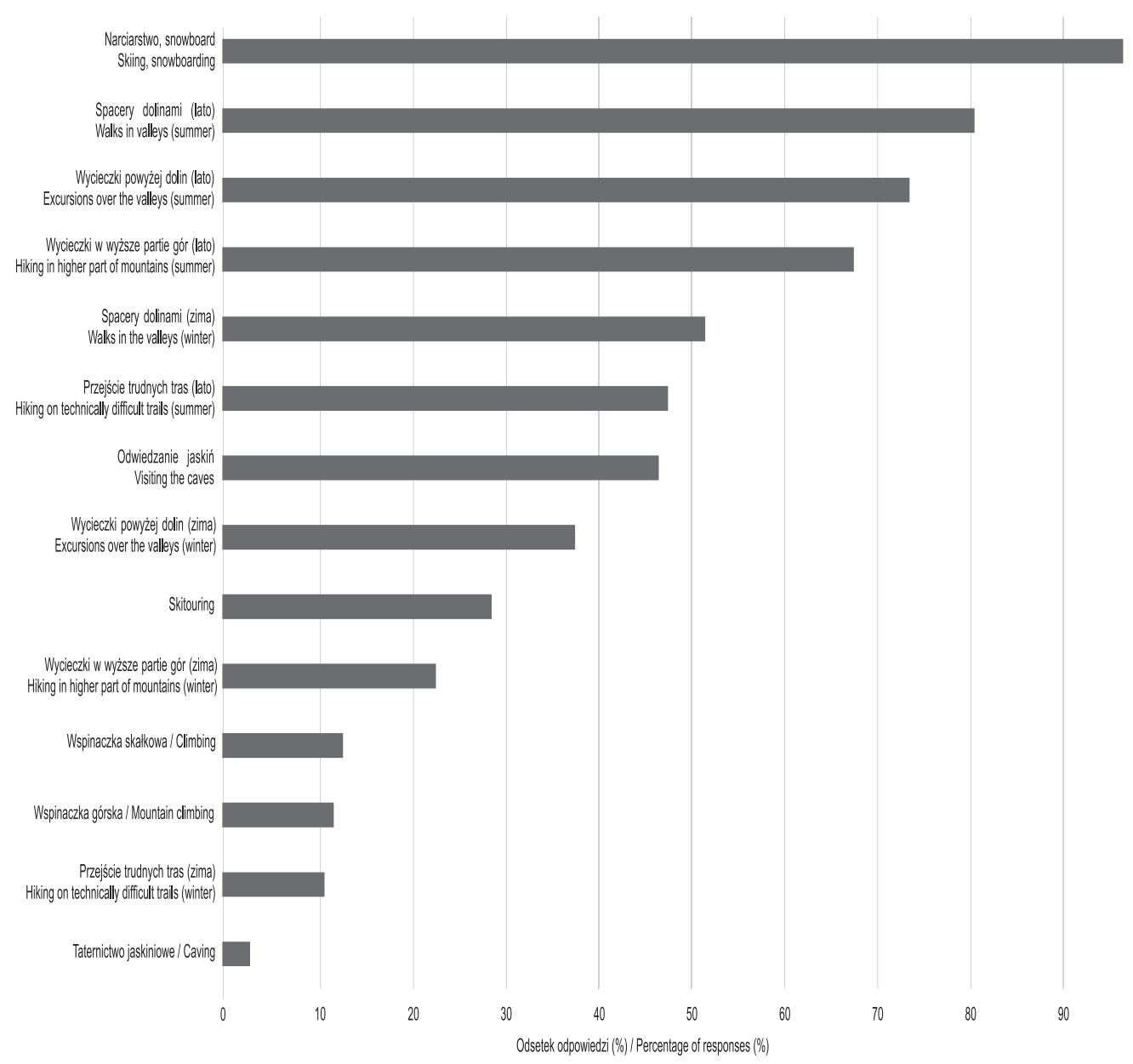

Ryc. 2. Wcześniejsze doświadczenia górskie - inne formy aktywności uprawiane przez respondentów w górach

Fig. 2. Past mountain experience - other activities conducted by respondents in the mountains Źródto: na podstawie Hibner 2018.

Source: based on Hibner 2018.

Na podstawie testów statystycznych Kruskala - Wallisa, U Manna - Whitneya, a w niektórych przypadkach tau-b Kendalla stwierdzono, iż zmienna wcześniejsze doświadcæenia górskie respondentów w postaci liczby innych aktywności uprawianych w górach istotnie wpływa na właściwie wszystkie zmienne ujęte w niniejszym opra- 
cowaniu. Zwłaszcza na zmienne dotyczące motywów wyjazdu na narty, powodów, dla których respondenci wybrali badane ośrodki narciarskie, a także na częstotliwość przyjazdów. Nie zaobserwowano jedynie istotnych statystycznie zależności między liczbą innych aktywności uprawianych w górach a zmiennymi o charakterze społeczno-demograficznym (wiek, płeć; tab. 7).

Tab. 7. Zależność zmiennej wcześniejsze doświadczenia górskie (liczba aktywności uprawianych do tej pory w górach) od innych zmiennych ujętych w opracowaniu - wyniki testów Kruskala Wallisa, U Manna - Whitneya oraz tau-b Kendalla

Table 7. Past mountain experience (number of other activities conducted in the mountains during respondents' life) analysed in terms of other variables included in this research - results of statistical tests: Kruskal - Wallis, U Mann - Whitney and tau-b Kendall

\begin{tabular}{|c|c|c|}
\hline \multicolumn{3}{|c|}{$\begin{array}{l}\text { Wcześniejsze doświadczenia górskie (liczba aktywności uprawianych do tej pory w górach) } \\
\text { Past mountain experience (number of other activities conducted in mountains during respondents' life) }\end{array}$} \\
\hline & \multicolumn{2}{|c|}{ Test Kruskala - Wallisa } \\
\hline & $\begin{array}{l}\text { wartość H } \\
\text { H value }\end{array}$ & $\begin{array}{l}\text { istotność asymptotyczna } \\
\text { asymp. Sig. }\end{array}$ \\
\hline $\begin{array}{l}\text { Pobyt w ośrodkach narciarskich } \\
\text { Stay in another ski resorts }\end{array}$ & 8,515 & 0,036 \\
\hline $\begin{array}{l}\text { Motyw wyjazdu } \\
\text { Tourists' motive }\end{array}$ & 33,311 & 0,001 \\
\hline $\begin{array}{l}\text { Czynnik wyboru wskazanego ośrodka } \\
\text { Factor for choosing the particular ski } \\
\text { resort }\end{array}$ & 32,289 & 0,000 \\
\hline \multirow[t]{3}{*}{$\begin{array}{l}\text { Forma aktywności } \\
\text { Type of activity }\end{array}$} & 27,003 & 0,000 \\
\hline & \multicolumn{2}{|c|}{ Test U Manna - Whitneya } \\
\hline & $\begin{array}{l}\text { wartość } Z \\
\text { Z value }\end{array}$ & $\begin{array}{l}\text { istotność asymptotyczna } \\
\text { asymp. Sig. }\end{array}$ \\
\hline Obszar badań / Research area & $-4,557$ & 0,000 \\
\hline \multirow[t]{3}{*}{ Płeć / Gender } & $-1,175$ & 0,240 \\
\hline & \multicolumn{2}{|c|}{ Test tau-b Kendalla } \\
\hline & $\begin{array}{l}\text { wartość } \\
\text { value }\end{array}$ & $\begin{array}{l}\text { istotność przybliżona } \\
\text { approx. Sig. }\end{array}$ \\
\hline Wiek / Age & 0,055 & 0,162 \\
\hline $\begin{array}{l}\text { Częstotliwość przyjazdów } \\
\text { Frequency of visits }\end{array}$ & 0,199 & 0,000 \\
\hline
\end{tabular}

Źródto: na podstawie Hibner 2018.

Source: based on Hibner 2018. 
Na podstawie zebranych danych stwierdzono, że zmienna wcześniejsze doświadczenia górskie, rozumiana jako liczba innych aktywności uprawianych w górach przez respondentów, jest zależna od obszaru badań. Odnotowano, iż osoby ankietowane w rejonie Kasprowego Wierchu uprawiają więcej innych niż narciarskie form aktywności ruchowej w górach (połowa badanych uprawia od 5-9 różnych form aktywności) niż badani w rejonie Tatrzańskiej Łomnicy (połowa uprawia od 3-7 różnych form aktywności) (ryc. 3A). Zaobserwowano ponadto, że istnieje zależność między wcześniejszymi doświadczeniami górskim a częstotliwością przyjazdów do obydwu ośrodków narciarskich. Wraz ze wzrostem częstotliwości przyjazdów w celu uprawiania sportów zimowych rośnie liczba aktywności uprawianych przez ankietowanych w górach również latem. Respondenci, którzy przyjeżdżają kilka razy w sezonie do badanych ośrodków narciarskich, uprawiają więcej różnych form aktywności

Ryc. 3A-F. Wcześniejsze doświadczenia górskie (liczba uprawianych aktywności w górach) a pozostałe zmienne: A - obszar badań, B - częstotliwość przyjazdów, C - forma uprawianej aktywności, D - pobyt w innych ośrodkach, E - motywy wyjazdu, F - czynnik wyboru wskazanego ośrodka narciarskiego. Miary statystyczne: mediana i kwartyle

Fig. 3A-F. Past mountain experience (number of conducted activities in the mountains) analysed in terms of selected variables: A - research area, B - frequency of visits, C - type of conducted activity in the particular ski resort, D - stay in other ski resorts, E - tourists' motives, $\mathrm{F}$ - factor for choosing the particular ski resort. Statistical measures median and quartiles.

Objaśnienia: E - motyw wyjazdu: 1 - kontakt z naturą, 2-widoki, 3 -zamiłowanie do gór, 4 - odpoczynek psychiczny, 5 - potrzeba samotności, 6 - potrzeba aktywności fizycznej, 7 - motyw poznawczy, 8 - motyw zdrowotny, 9 - motyw ambicyjny, 10 - potrzeba spędzenia czasu z bliskimi, 11 - motyw społeczny, rozrywka, 12 - motyw sentymentalny, 13 - inne, 14 - brak głównego motywu

F - czynnik wyboru wskazanego ośrodka narciarskiego: 1 - wracam, bo lubię to miejsce, 2 - dobre warunki narciarskie, 3 - przyjaciele mnie zachęcili, 4 - sława renoma tego miejsca, 5 - chęć spróbowania swoich sił, 6 - inne, 7 - brak odpowiedzi

Explanations: E - tourists' motive: 1 - contact with nature, 2 - scenery, 3 - love for the mountains, 4 - mental well-being, 5 - solitude, 6 - need for physical activity, 7 - educational motive, 8 - health motive, 9 - ambition motive, 10 - time with family and friends, 11 - social motive, entertainment, 12 - sentimental motive, 13 - others, 14 - lack of main motive

F - factor for choosing the particular ski resort: 1 - I come back because I like this place, 2 - good ski conditions, 3 - my friends encouraged me to come here, 4 - fame, popularity of this place, 5 - I wanted to try my skills here, 6 - others, 7 - lack of an answer

Źródto: podstawie Hibner 2018.

Source: based on Hibner 2018. 

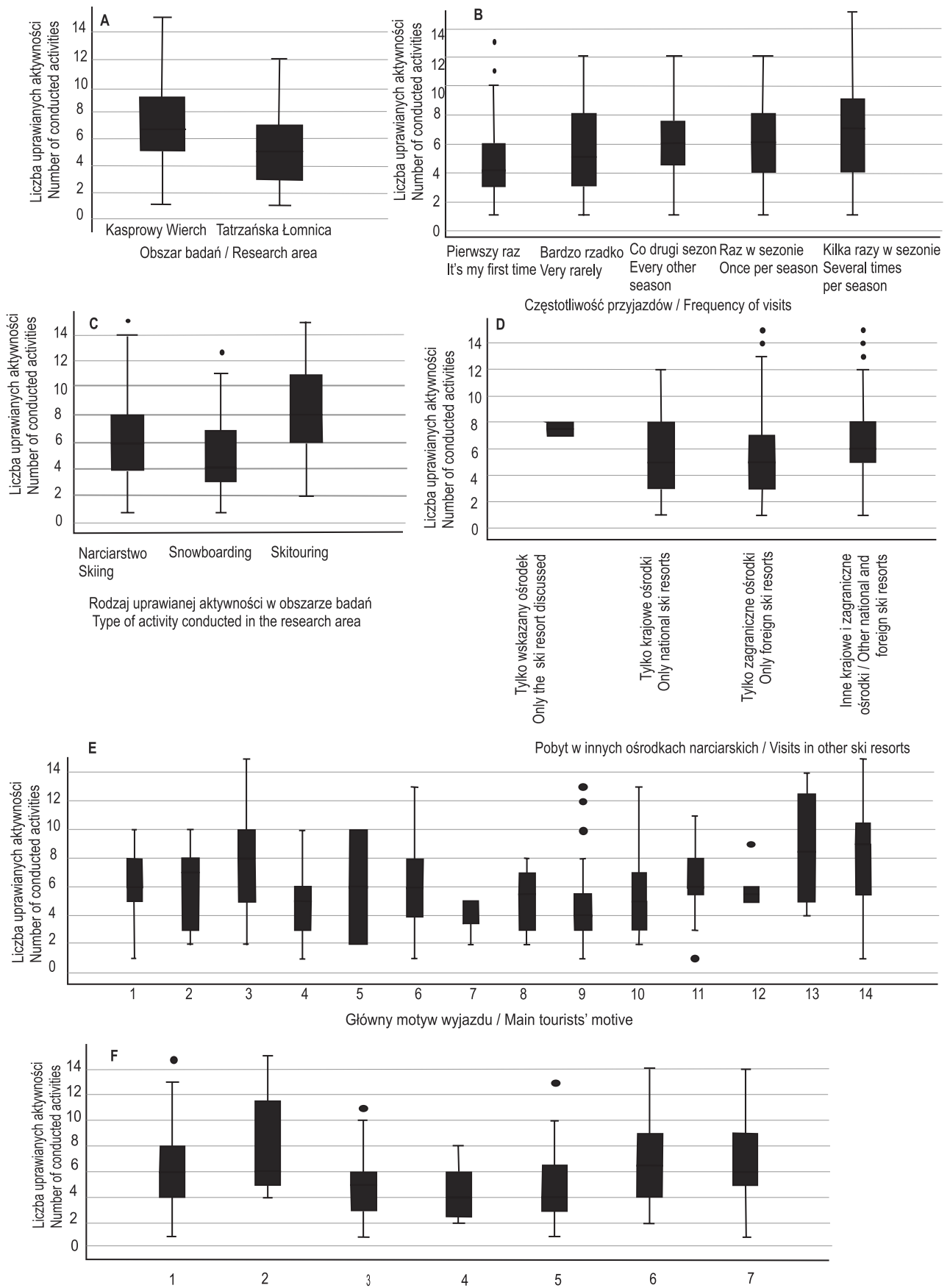

Czynniki wyboru wskazanego ośrodka / Factors for choosing particular ski resort 
ruchowej w górach (połowa badanych uprawia od 4-9 różnych form aktywności, maksymalnie 15) niż osoby, które przyjechały do obu ośrodków po raz pierwszy (połowa uprawia od 3-6 różnych form aktywności, maksymalnie 13) (ryc. 3B). Z badań wynika ponadto, iż osoby uprawiające skitouring posiadają bogatsze doświadczenia górskie, gdyż uprawiają więcej innych aktywności ruchowych (połowa uprawia od 6-11 różnych form aktywności) niż osoby, które przyjechały na narty czy snowboard (połowa snowboardzistów uprawia od 3-7 różnych form aktywności) (ryc. 3C). Stwierdzono także, iż zmienna wczesniejsæe doświadcæenia narciarskie respondentów (pobyt w innych ośrodkach narciarskich) jest istotnie zależna od zmiennej wczéniejsze doświadczenia górskie (liczba aktywności). Co ciekawe, najwięcej różnych form aktywności uprawiają ankietowani, którzy przyjeżdżają wyłącznie do badanych ośrodków narciarskich (całą badana grupa uprawia 7 lub 8 różnych form aktywności). Jest to jednak najmniej liczna grupa. Z zebranych danych wynika również, że osoby posiadające bogatsze doświadczenia narciarskie (czyli te, które miały okazję doświadczyć jazdy na nartach zarówno w krajowych, jak i zagranicznych ośrodkach narciarskich) mają jednocześnie szersze doświadczenia górskie (połowa uprawia powyżej 6 różnych aktywności poza narciarstwem) (ryc. 3D).

Zmienna wcæéniejsze doświadczenia górskie jest również zależna od motywu wyjazdu na narty, jaki deklarowali respondenci. Odnotowano, iż istotnie więcej różnych form aktywności górskich uprawiają ankietowani, dla których głównym motywem wyjazdu na narty była potrzeba spędzenia czasu w górach, widoki i przyroda. Natomiast zdecydowanie mniej aktywności górskich uprawiają osoby, dla których liczył się przede wszystkim motyw ambicyjny (ryc. 3E). Istotne zależności zaobserwowano również między wczéniejszymi doświadczeniami górskimi a powodem, dla którego respondenci wybrali wskazane ośrodki narciarskie. Najwięcej różnych form turystyki górskiej uprawiają osoby, dla których liczyły się dobre warunki narciarskie lub sentyment do wskazanego ośrodka narciarskiego. Najmniej różnych form turystyki uprawiają ci respondenci, dla których liczyła się sława, renoma ośrodka (ryc. 3F).

Z przeprowadzonych badań wynika, iż respondenci przyjechali w góry przede wszystkim dla zaspokojenia potrzeb ruchowych (ok. 30\%). Odnotowano ponadto, że czynniki związane $\mathrm{z}$ aspektem przyrodniczym (kontakt z przyrodą, zamiłowanie do gór, widoki), mimo iż często wskazywane przez respondentów, nie stanowiły dominującego motywu. Bardzo ważny okazał się także motyw związany z potrzebą odpoczynku psychicznego, relaksu (12\%). Istnieje także nieliczna grupa respondentów, dla której pobyt w górach na nartach lub snowboardzie jest formą spędzenia czasu z bliskimi (rodzina/przyjaciele - 8\%). Dla innych uprawianie sportów zimowych w obu ośrodkach jest sposobem na zaimponowanie innym (również 8\%; ryc. 4).

$\mathrm{Na}$ podstawie testu statystycznego $\mathrm{Chi}^{2}$ stwierdzono istotne statystycznie zależności między główną motywacją respondentów do uprawiania turystyki narciarskiej a obszarem badań. Największe różnice zaobserwowano między respondentami, 


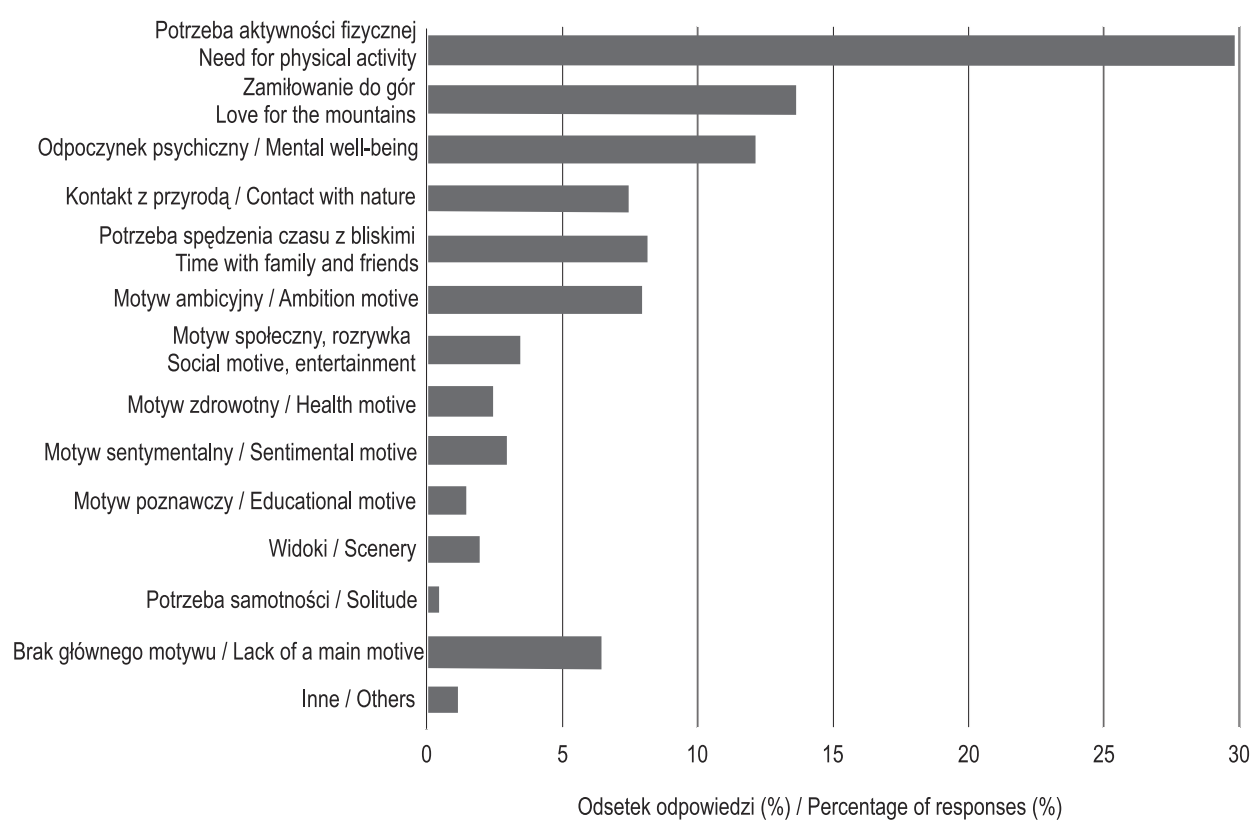

Ryc. 4. Główne motywy uprawiania turystyki narciarskiej w badanych ośrodkach Fig. 4. Main motives for conducting skiing in the research areas Źródto: na podstawie Hibner 2018.

Source: based on Hibner 2018.

którzy jako główny motyw swojego wyjazdu deklarowali potrzebę aktywnego spędzenia czasu. Co prawda był to najczęściej wybierany powód wśród badanych w obu ośrodkach, jednakże w rejonie Kasprowego Wierchu odnotowano większy odsetek osób (35\%), które zadeklarowały potrzebę aktywności ruchowej jako główny powód wyjazdu do wskazanego ośrodka narciarskiego. W rejonie Tatrzańskiej Łomnicy zaobserwowano także większy odsetek respondentów, dla których wyjazd w celu uprawiania sportów zimowych był spowodowany potrzebą odpoczynku, oderwania się od codzienności (16\%). Różnicę zarejestrowano również wśród ankietowanych, dla których potrzeba kontaktu z przyrodą była głównym motywem wyjazdu. W rejonie Tatrzańskiej Łomnicy odnotowano nieco większy odsetek respondentów deklarujących ten motyw (tab. 8).

Test $\mathrm{Chi}^{2}$ wykazał również zależność między motywem wyjazdu oraz częstotliwością przyjazdów do wskazanych ośrodków narciarskich. Zaobserwowano, że odsetek respondentów deklarujących potrzebę odpoczynku psychicznego oraz potrzebę spędzenia czasu z najbliższymi jest większy wśród osób rzadziej odwiedzających wskazane ośrodki 
Tab. 8. Motywacje respondentów uprawiających sporty zimowe z obydwu ośrodków narciarskich

Table 8. Tourists' motives from both research areas

\begin{tabular}{|c|c|c|c|c|}
\hline \multirow{2}{*}{$\begin{array}{l}\text { Motywacje respondentów } \\
\text { Tourists' motives }\end{array}$} & \multicolumn{2}{|c|}{$\begin{array}{l}\text { Odsetek odpowiedzi (\%) } \\
\text { Percentage pf responses (\%) }\end{array}$} & \multicolumn{2}{|r|}{ Test Chi2 } \\
\hline & $\begin{array}{l}\text { Kasprowy } \\
\text { Wierch }\end{array}$ & $\begin{array}{l}\text { Tatrzańska } \\
\text { Łomnica }\end{array}$ & $\begin{array}{l}\text { wartość } \\
\text { value }\end{array}$ & \begin{tabular}{|} 
istotność asymptotyczna \\
(dwustronna) \\
asymp. Sig. 2-sided
\end{tabular} \\
\hline Kontakt z przyrodą / Contact with nature & 5 & 10 & \multirow{15}{*}{31,636} & \multirow{15}{*}{0,003} \\
\hline Widoki / Scenery & 4 & 0 & & \\
\hline Zamiłowanie do gór / Love for the mountains & 13 & 14 & & \\
\hline Odpoczynek psychiczny / Mental well-being & 8 & 16 & & \\
\hline Potrzeba samotności / Solitude & 1 & 1 & & \\
\hline $\begin{array}{l}\text { Potrzeba aktywności ruchowej } \\
\text { Need for physical activity }\end{array}$ & 35 & 25 & & \\
\hline Motyw poznawczy / Educational motive & 3 & 1 & & \\
\hline Motyw zdrowotny / Health motive & 2 & 3 & & \\
\hline Motyw ambicyjny / Ambitional motive & 8 & 8 & & \\
\hline $\begin{array}{l}\text { Potrzeba spędzenia czasu z bliskimi } \\
\text { Time with family \& friends }\end{array}$ & 8 & 8 & & \\
\hline $\begin{array}{l}\text { Motyw społeczny, rozrywka } \\
\text { Social motive, entertainment }\end{array}$ & 1 & 5 & & \\
\hline Motyw sentymentalny / Sentimental motive & 4 & 2 & & \\
\hline Inne / Others & 1 & 1 & & \\
\hline $\begin{array}{l}\text { Brak głównego motywu } \\
\text { Lack of a main motive }\end{array}$ & 7 & 6 & & \\
\hline Razem / Total & 100 & 100 & & \\
\hline
\end{tabular}

Źródto: na podstawie Hibner 2018.

Source: based on Hibner 2018.

narciarskie. Natomiast odsetek ankietowanych, którzy za główny motyw swojego wyjazdu uznali zamiłowanie do gór, wzrasta wraz z większą częstotliwością przyjazdów do obu ośrodków narciarskich (tab. 9).

Stwierdzono silną zależność pomiędzy motywem wyjazdów w celu uprawiania turystyki narciarskiej a wiekiem respondentów. W najmłodszej grupie wiekowej odnotowano największy odsetek ankietowanych, dla których głównym motywem wyjazdu była potrzeba aktywności ruchowej. Jednocześnie w grupie młodych respondentów, do 34. roku życia, stwierdzono najniższy odsetek osób, dla których potrzeba kontaktu z przyrodą była głównym powodem wyjazdu. Odnotowano ponadto, iż wraz z wiekiem respondentów spadał odsetek osób, dla których istotą 
Tab. 9. Motywacje respondentów uprawiających sporty zimowe w zależności od częstotliwości przyjazdów do wskazanych ośrodków narciarskich

Table 9. Tourists' motives analysed in terms of the frequency of visits

\begin{tabular}{|c|c|c|c|c|c|c|c|}
\hline \multirow[b]{2}{*}{$\begin{array}{c}\text { Motywacje } \\
\text { respondentów } \\
\text { Tourists' motives }\end{array}$} & \multicolumn{5}{|c|}{$\begin{array}{l}\text { Częstotliwość przyjazdów (\%) } \\
\text { Frequency of visits }\end{array}$} & \multicolumn{2}{|c|}{ Test Chi² } \\
\hline & $\begin{array}{c}\text { pierwszy raz } \\
\text { it's my first } \\
\text { time }\end{array}$ & $\begin{array}{l}\text { bardzo rzadko } \\
\text { very rarely }\end{array}$ & \begin{tabular}{|c} 
co drugi \\
sezon \\
every other \\
season
\end{tabular} & $\begin{array}{c}\text { raz w } \\
\text { sezonie } \\
\text { once per } \\
\text { season }\end{array}$ & \begin{tabular}{|c|} 
kilka razy \\
w sezonie \\
several \\
times per \\
season
\end{tabular} & $\begin{array}{l}\text { wartość } \\
\text { value }\end{array}$ & \begin{tabular}{|c|} 
istotność \\
asymptotyczna \\
(dwustronna) \\
asymp. Sig. \\
2-sided \\
\end{tabular} \\
\hline $\begin{array}{l}\text { Kontakt z przyrodą } \\
\text { Contact with nature }\end{array}$ & 3 & 7 & 13 & 6 & 11 & \multirow{14}{*}{81,545} & \multirow{14}{*}{0,006} \\
\hline Widoki / Scenery & 3 & 0 & 0 & 2 & 2 & & \\
\hline $\begin{array}{l}\text { Zamiłowanie do gór } \\
\text { Love for the mountains }\end{array}$ & 8 & 7 & 17 & 15 & 18 & & \\
\hline $\begin{array}{l}\text { Odpoczynek psychiczny } \\
\text { Mental well-being }\end{array}$ & 19 & 13 & 13 & 11 & 9 & & \\
\hline $\begin{array}{l}\text { Potrzeba samotności } \\
\text { Solitude }\end{array}$ & 0 & 0 & 0 & 0 & 1 & & \\
\hline $\begin{array}{l}\text { Potrzeba aktywności } \\
\text { ruchowej } \\
\text { Need for physical } \\
\text { activity }\end{array}$ & 26 & 46 & 18 & 31 & 28 & & \\
\hline $\begin{array}{l}\text { Motyw poznawczy } \\
\text { Educational motive }\end{array}$ & 6 & 0 & 0 & 0 & 0 & & \\
\hline $\begin{array}{l}\text { Motyw zdrowotny } \\
\text { Health motive }\end{array}$ & 1 & 2 & 0 & 5 & 3 & & \\
\hline $\begin{array}{l}\text { Motyw ambicyjny } \\
\text { Ambitional motive }\end{array}$ & 9 & 2 & 18 & 7 & 8 & & \\
\hline $\begin{array}{l}\text { Potrzeba spędzenia } \\
\text { czasu z bliskimi } \\
\text { Time with family } \\
\text { \& friends }\end{array}$ & 14 & 13 & 4 & 8 & 4 & & \\
\hline $\begin{array}{l}\text { Motyw społeczny, } \\
\text { rozrywka } \\
\text { Social motive, } \\
\text { entertainment }\end{array}$ & 5 & 2 & 4 & 2 & 3 & & \\
\hline $\begin{array}{l}\text { Motyw sentymentalny } \\
\text { Sentimental motive }\end{array}$ & 1 & 2 & 9 & 6 & 2 & & \\
\hline Inne / Others & 0 & 4 & 0 & 1 & 1 & & \\
\hline $\begin{array}{l}\text { Brak głównego motywu } \\
\text { Lack of a main motive }\end{array}$ & 4 & 2 & 4 & 6 & 10 & & \\
\hline Razem / Total & 100 & 100 & 100 & 100 & 100 & & \\
\hline
\end{tabular}

Źródto: na podstawie Hibner 2018.

Source: based on Hibner 2018. 
wyjazdu narciarskiego była potrzeba spędzenia czasu z bliskimi. Natomiast w najstarszej grupie wiekowej zarejestrowano największy odsetek osób, które podczas wyjazdu szukały samotności. Motyw ambicyjny stwierdzono przede wszystkim wśród najmłodszych respondentów. Zaobserwowano także, iż wraz z wiekiem potrzeba „sprawdzenia się”, ,zaimponowania innym” na ogół spada, poza najstarszą grupą wiekową (po 64. roku życia).

Z badań wynika także, iż wraz z wiekiem ankietowanych rósł odsetek osób, dla których głównym powodem wyjazdu narciarskiego było zdrowie (tab. 10.).

Zaobserwowano także zależności między motywem wyjazdu a powodami, dla których respondenci wybrali ośrodki narciarskie objęte badaniem. Największy odsetek respondentów, dla których istotny był motyw związany z potrzebą aktywności ruchowej, zaobserwowano w grupie osób, które wybrały badane ośrodki narciarskie ze względu na dobre warunki do uprawiania sportów zimowych (47\%). Zamiłowanie do gór jest istotnym motywem wśród ankietowanych, którzy wybrali badane ośrodki narciarskie z pobudek sentymentalnych, jak również ze względu na dobre warunki narciarskie. Największy odsetek motywów związanych z odpoczynkiem psychicznym, a także potrzebą spędzenia czasu z najbliższymi, zanotowano w grupie respondentów, którzy wybrali wskazane ośrodki narciarskie ze względu na ich „renomę”, zachętę ze strony najbliższych oraz by spróbować swoich sił w tych konkretnych ośrodkach jako narciarze (tab. 11).

Nie zaobserwowano zależności między motywem wyjazdu a płcią respondentów czy też formami aktywności uprawianymi przez ankietowanych w obu ośrodkach narciarskich.

Wedle przeprowadzonych badań blisko połowa respondentów za główny czynnik wyboru tych konkretnych ośrodków narciarskich podała odpowiedź: , wracam tu, bolubię to miejsce" (44\%). Ten czynnik sentymentalny przejawiał się dość często w rozmowach z respondentami, szczególnie na Kasprowym Wierchu, pomimo często negatywnego stosunku do funkcjonowania ośrodka jako całości. W przypadku Kasprowego Wierchu istotny był także czynnik związany z dobrymi warunkami narciarskimi (16\%). Chodzi tu o charakter tras, a przede wszystkim o dobre warunki śniegowe. Ten czynnik był dość często wymieniany przez respondentów w sezonie zimowym 2014/2015, kiedy to warunki śniegowe były dość trudne, a Kasprowy Wierch był jednym z nielicznych funkcjonujących ośrodków. Około 12\% respondentów z Tatrzańskiej Łomnicy wybrało to miejsce ze względu na jego sławę, renomę. Około 14\% respondentów zadeklarowało, że rodzina lub przyjaciele zachęcili ich do wyboru tych ośrodków. Dla nielicznej grupy respondentów (9\%) wybór wskazanych ośrodków był spowodowany chęcią spróbowania swoich sił. Wynika z tego, że istnieje grupa respondentów, dla których Kasprowy Wierch i Tatrzańska Łomnica stanowią pewien etap w rozwoju umiejętności narciarskich (ryc. 5; tab. 12). 
Tab. 10. Motywacje respondentów uprawiających sporty zimowe ze względu na wiek Table 10. Tourists' motives analysed in terms of respondents' age

\begin{tabular}{|c|c|c|c|c|c|c|c|c|c|}
\hline \multirow[b]{2}{*}{$\begin{array}{l}\text { Motywacje } \\
\text { respondentów } \\
\text { Tourists' motives }\end{array}$} & \multicolumn{7}{|c|}{ Wiek (\%) / Age (\%) } & \multicolumn{2}{|c|}{ Test Chi ${ }^{2}$} \\
\hline & $\begin{array}{l}\text { poniżej } 18 \\
\text { less than } 18\end{array}$ & $\begin{array}{c}\text { wiek } \\
18-24\end{array}$ & $\begin{array}{c}\text { wiek } \\
25-34\end{array}$ & $\begin{array}{c}\text { wiek } \\
35-44\end{array}$ & $\begin{array}{c}\text { wiek } \\
45-54\end{array}$ & $\begin{array}{c}\text { wiek } \\
55-64\end{array}$ & $\begin{array}{c}\text { powyżej } 64 \\
64 \text { and } \\
\text { above }\end{array}$ & $\begin{array}{c}\text { wartość } \\
\text { value }\end{array}$ & $\begin{array}{c}\text { istotność } \\
\text { asymptotyczna } \\
\text { (dwustronna) } \\
\text { asymp. Sig. } \\
\text { 2-sided }\end{array}$ \\
\hline $\begin{array}{l}\text { Kontakt z przyrodą } \\
\text { Contact with nature }\end{array}$ & 7 & 0 & 5 & 8 & 10 & 15 & 9 & \multirow{15}{*}{104,171} & \multirow{15}{*}{0,026} \\
\hline Widoki / Scenery & 0 & 0 & 3 & 2 & 3 & 0 & 0 & & \\
\hline $\begin{array}{l}\text { Zamiłowanie do gór } \\
\text { Love for the mountains }\end{array}$ & 7 & 12 & 18 & 12 & 13 & 12 & 9 & & \\
\hline $\begin{array}{l}\text { Odpoczynek psychiczny } \\
\text { Mental well-being }\end{array}$ & 0 & 15 & 12 & 14 & 11 & 15 & 0 & & \\
\hline $\begin{array}{l}\text { Potrzeba samotności } \\
\text { Solitude }\end{array}$ & 0 & 0 & 0 & 0 & 1 & 0 & 9 & & \\
\hline $\begin{array}{l}\text { Potrzeba aktywności } \\
\text { ruchowej } \\
\text { Need for physical activity }\end{array}$ & 40 & 29 & 24 & 27 & 37 & 36 & 36 & & \\
\hline $\begin{array}{l}\text { Motyw poznawczy } \\
\text { Educational motive }\end{array}$ & 0 & 6 & 2 & 1 & 1 & 0 & 0 & & \\
\hline $\begin{array}{l}\text { Motyw zdrowotny } \\
\text { Health motive }\end{array}$ & 0 & 0 & 2 & 4 & 1 & 6 & 9 & & \\
\hline $\begin{array}{l}\text { Motyw ambicyjny } \\
\text { Ambitional motive }\end{array}$ & 20 & 9 & 12 & 3 & 6 & 3 & 9 & & \\
\hline $\begin{array}{l}\text { Potrzeba spędzenia czasu } \\
\text { z bliskimi } \\
\text { Time with family \& friends }\end{array}$ & 20 & 6 & 10 & 7 & 9 & 3 & 0 & & \\
\hline $\begin{array}{l}\text { Motyw społeczny, } \\
\text { rozrywka } \\
\text { Social motive, enterta- } \\
\text { inment }\end{array}$ & 6 & 9 & 3 & 5 & 1 & 0 & 0 & & \\
\hline $\begin{array}{l}\text { Motyw sentymentalny } \\
\text { Sentimental motive }\end{array}$ & 0 & 12 & 0 & 2 & 4 & 6 & 9 & & \\
\hline Inne / Others & 0 & 3 & 1 & 3 & 0 & 0 & 0 & & \\
\hline $\begin{array}{l}\text { Brak głównego motywu } \\
\text { Lack of a main motive }\end{array}$ & 0 & 0 & 8 & 11 & 3 & 3 & 9 & & \\
\hline Razem / Total & 100 & 100 & 100 & 100 & 100 & 100 & 100 & & \\
\hline
\end{tabular}

Źródto: na podstawie Hibner 2018.

Source: based on Hibner 2018. 


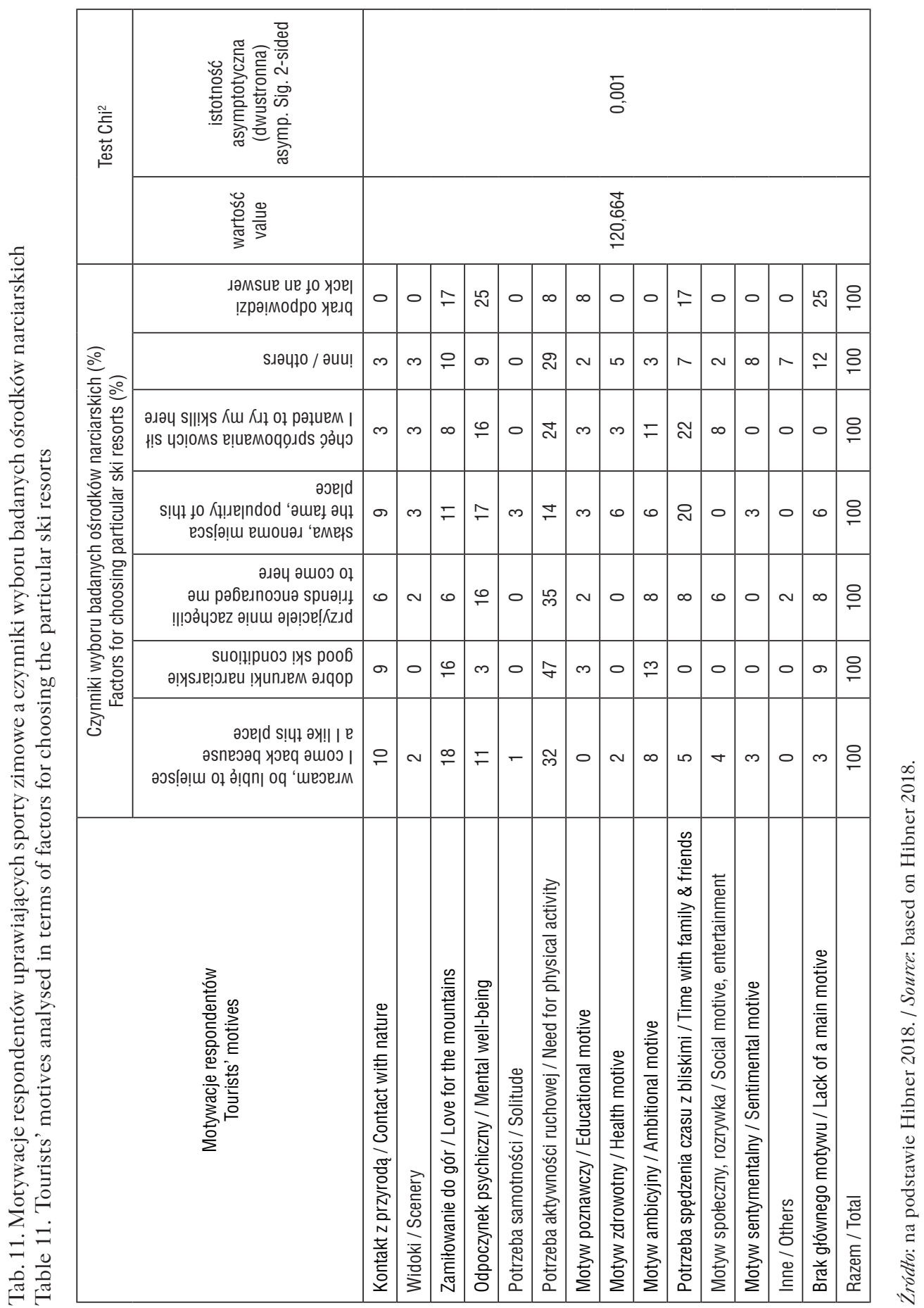




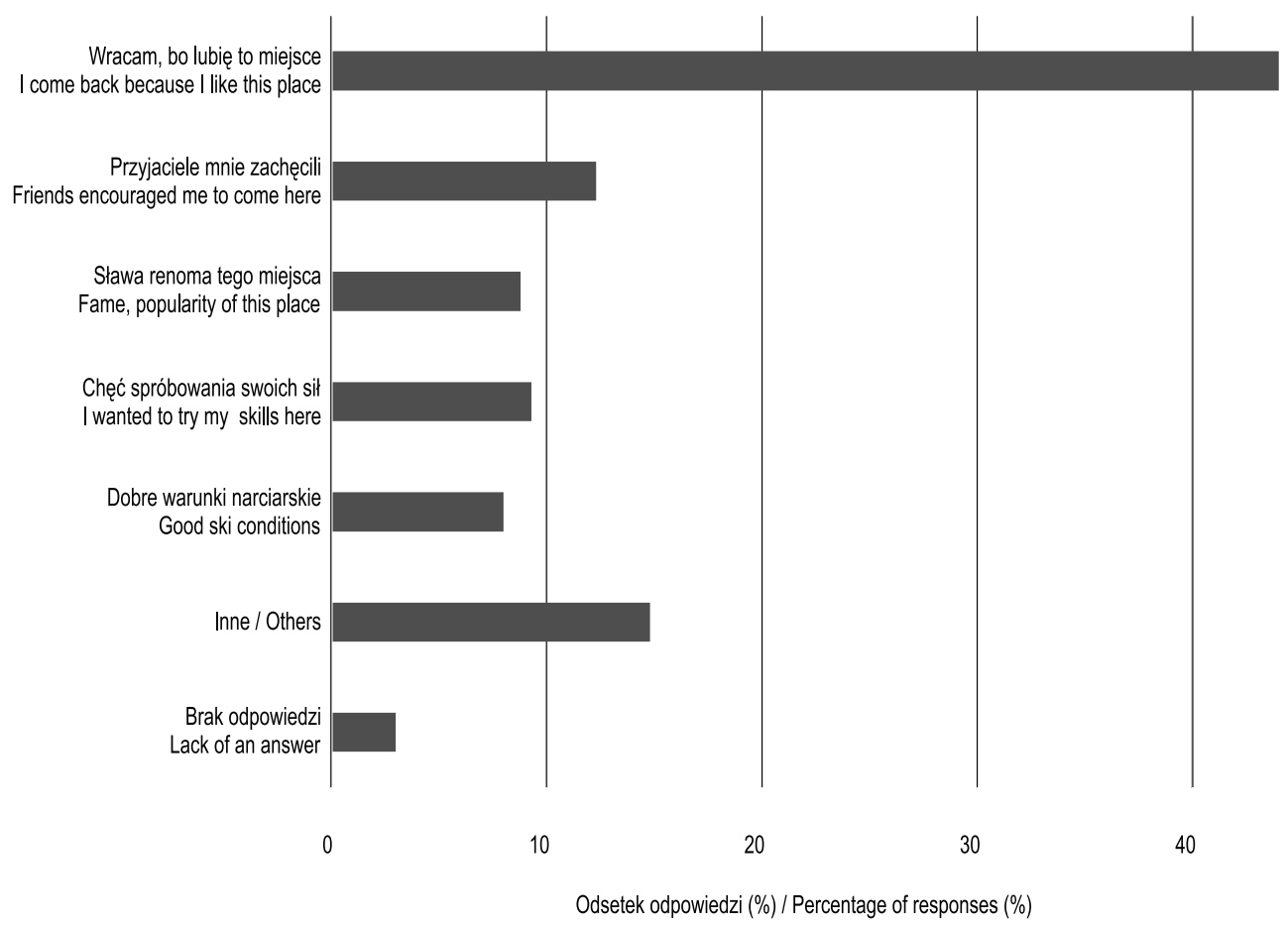

Ryc. 5. Czynnik wyboru wskazanych ośrodków narciarskich

Fig. 5. Factor for choosing the particular ski resorts

Źródto: na podstawie Hibner 2018.

Source: based on Hibner 2018.

Z przeprowadzonych badań wynika, że na czynnik wyboru badanych ośrodków narciarskich wpływają, poza miejscem, wcześniejszymi doświadczeniami górskimi i narciarskimi oraz motywami, także inne zmienne: przede wszystkim niektóre o charakterze społeczno-demograficznym, np. wiek respondentów (tab. 13), rodzaj uprawianej aktywności w obszarach badań (tab. 14) oraz częstotliwość przyjazdów (tab. 15). Stwierdzono między innymi istotną statystycznie zależność między wiekiem respondentów a wyborem badanych ośrodków z pobudek sentymentalnych. Zaobserwowano, iż odsetek odpowiedzi „wracam, bo lubię to miejsce” wzrasta wraz z wiekiem respondentów i jest największy w grupie między 55. a 64. rokiem życia (67\%). Może to wynikać z faktu, iż osoby, aktualnie po 50. roku życia, w czasach swojej młodości miały ograniczony dostęp do innych ośrodków narciarskich z uwagi na ówczesną sytuację polityczną w Polsce. W młodszych grupach wiekowych, do 34. roku życia, odnotowano natomiast większy odsetek respondentów, którzy wybrali 


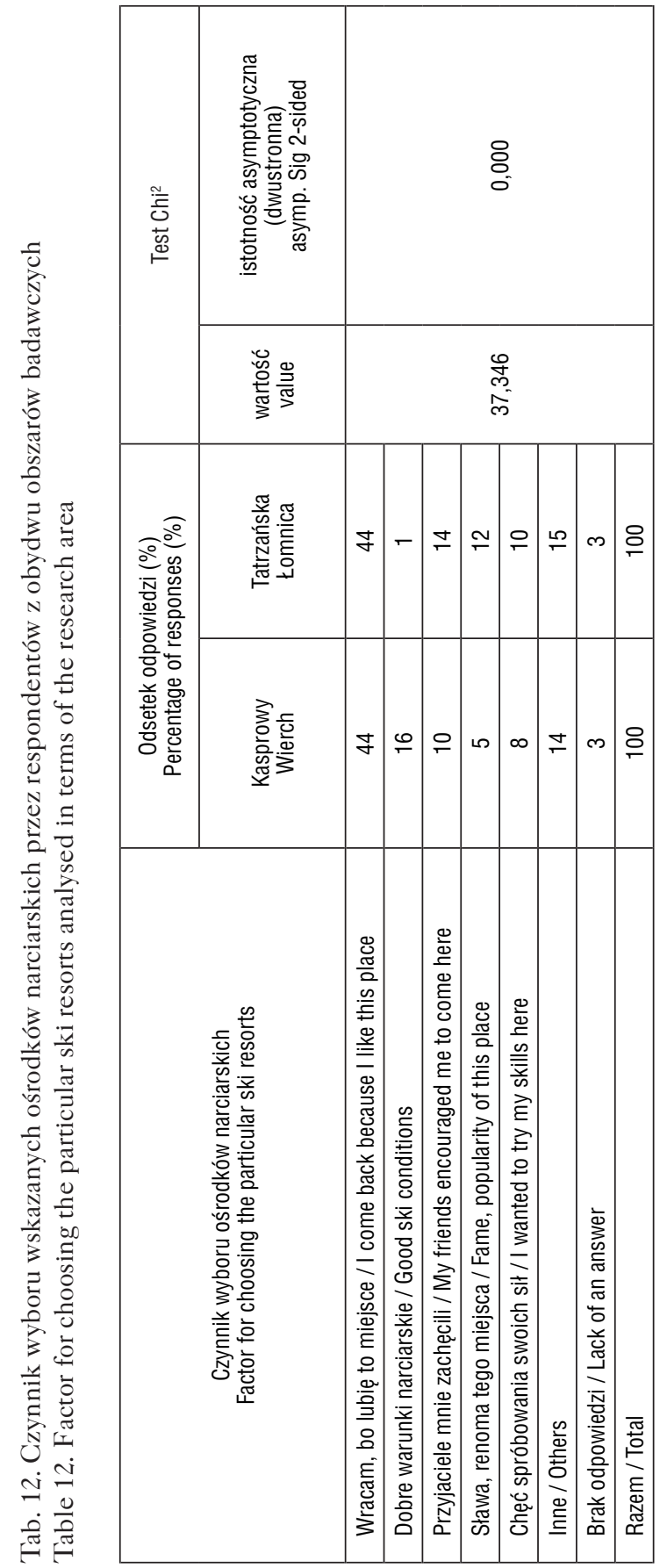

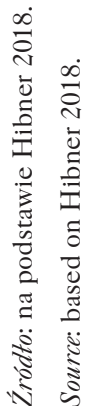




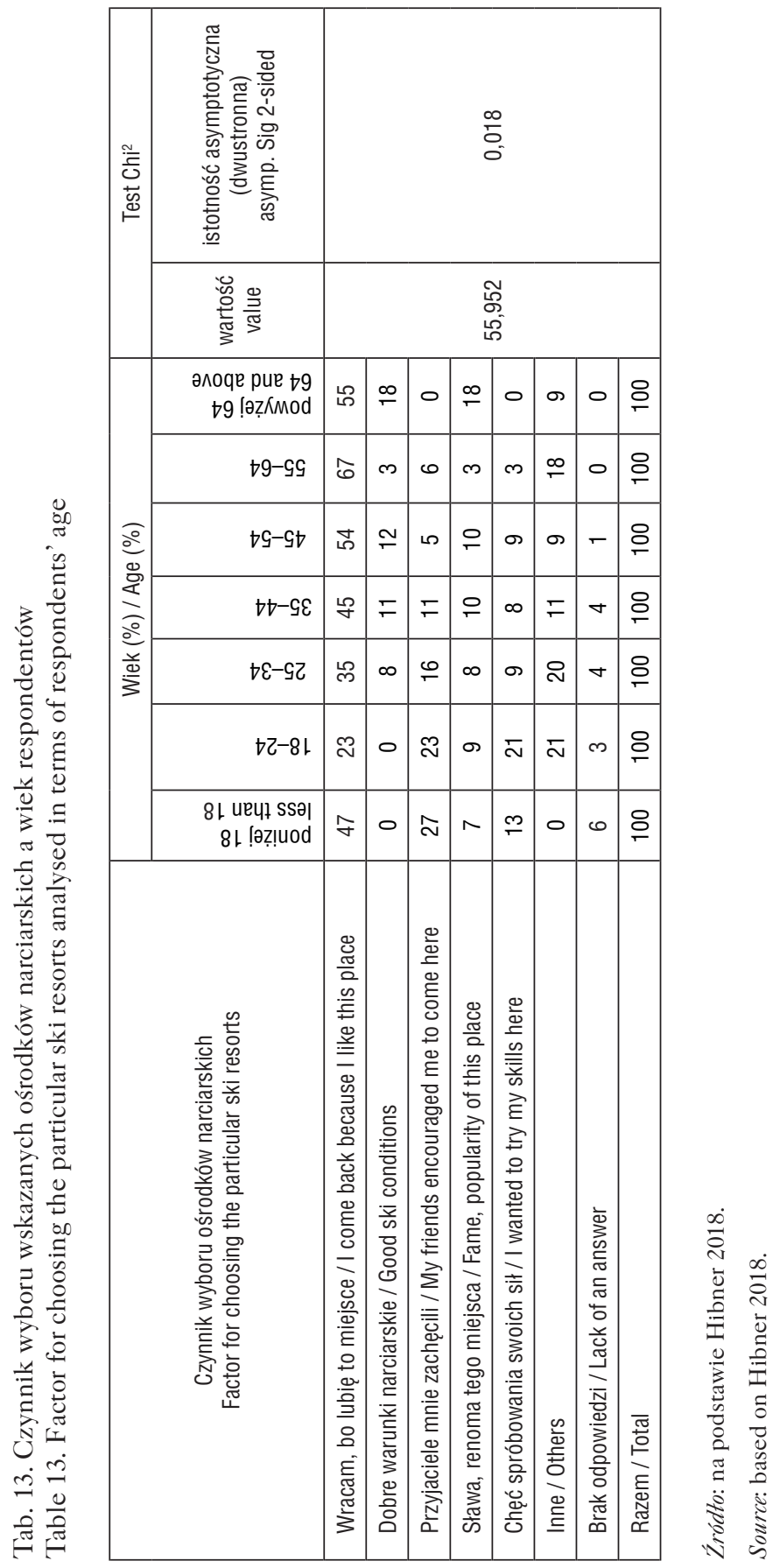


badane ośrodki narciarskie zachęceni przez przyjaciół (najwięcej, bo 27\% w grupie wiekowej poniżej 18. roku życia), a także by spróbować swoich sił/umiejętności narciarskich (najwięcej, bo 21\% w grupie wiekowej 18-24; tab. 13).

$\mathrm{Na}$ podstawie testu $\mathrm{Chi}^{2}$ potwierdzono również istotne statystycznie różnice między formą aktywności a powodem, dla którego respondenci wybierali wskazane ośrodki narciarskie. W grupie osób uprawiających narciarstwo odnotowano największy odsetek osób, które wybrały obszary badawcze z pobudek sentymentalnych (48\%). Osoby uprawiające skitouring również deklarowały czynnik sentymentalny przy wyborze miejsca (40\%), ale dla tej grupy istotne były ponadto dobre warunki narciarskie (21\%). W grupie respondentów uprawiających snowboarding odnotowano zdecydowanie mniejszy odsetek powodów sentymentalnych (25\%). Natomiast taki sam odsetek snowboardzistów zadeklarował, iż wybrał badane ośrodki narciarskie

Tab. 14. Czynnik wyboru wskazanych ośrodków narciarskich w zależności od rodzaju uprawianej aktywności w badanych ośrodkach

Table 14. Factor for choosing the particular ski resorts analysed in terms of the type of activity conducted in both ski resorts

\begin{tabular}{|c|c|c|c|c|c|}
\hline \multirow{2}{*}{$\begin{array}{l}\text { Czynnik wyboru ośrodków } \\
\text { narciarskich } \\
\text { Factor for choosing } \\
\text { the particular ski resorts }\end{array}$} & \multicolumn{3}{|c|}{$\begin{array}{c}\text { Rodzaj aktywności (\%) } \\
\text { Type of activity (\%) }\end{array}$} & \multicolumn{2}{|r|}{ Test Chi² } \\
\hline & $\begin{array}{l}\text { narciarstwo } \\
\text { skiing }\end{array}$ & snowboarding & skitouring & $\begin{array}{l}\text { wartość } \\
\text { value }\end{array}$ & $\begin{array}{c}\text { istotność } \\
\text { asymptotyczna } \\
\text { (dwustronna) } \\
\text { asymp. Sig 2-sided }\end{array}$ \\
\hline $\begin{array}{l}\text { Wracam, bo lubię to miejsce } \\
\text { I come back because I like } \\
\text { this place }\end{array}$ & 48 & 25 & 40 & \multirow{8}{*}{46,281} & \multirow{8}{*}{0,000} \\
\hline $\begin{array}{l}\text { Dobre warunki narciarskie } \\
\text { Good ski conditions }\end{array}$ & 7 & 4 & 21 & & \\
\hline $\begin{array}{l}\text { Przyjaciele mnie zachęcili } \\
\text { My friends encouraged me } \\
\text { to come here }\end{array}$ & 11 & 25 & 2 & & \\
\hline $\begin{array}{l}\text { Sława, renoma tego miejsca } \\
\text { Fame, popularity of this place }\end{array}$ & 9 & 13 & 4 & & \\
\hline $\begin{array}{l}\text { Chęć spróbowania swoich sił } \\
\text { I wanted to try my skills here }\end{array}$ & 10 & 14 & 2 & & \\
\hline Inne / Others & 13 & 12 & 25 & & \\
\hline $\begin{array}{l}\text { Brak odpowiedzi } \\
\text { Lack of an answer }\end{array}$ & 2 & 7 & 6 & & \\
\hline Razem / Total & 100 & 100 & 100 & & \\
\hline
\end{tabular}

Źródto: na podstawie Hibner 2018.

Source: based on Hibner 2018. 
Tab. 15. Czynnik wyboru wskazanych ośrodków narciarskich w zależności od częstotliwości przyjazdów do badanych ośrodków

Table 15. Factor for choosing the particular ski resorts analysed in terms of the frequency of visits

\begin{tabular}{|c|c|c|c|c|c|c|c|}
\hline \multirow[b]{2}{*}{$\begin{array}{l}\text { Czynnik wyboru ośrodków } \\
\text { narciarskich } \\
\text { Factor for choosing } \\
\text { the particular ski resorts }\end{array}$} & \multicolumn{5}{|c|}{ Częstotliwość przyjazdów (\%) / Frequency of visits (\%) } & \multicolumn{2}{|c|}{ Test Chi² } \\
\hline & $\begin{array}{l}\text { pierwszy raz } \\
\text { l'm first time }\end{array}$ & \begin{tabular}{|c|} 
bardzo \\
rzadko \\
very \\
rarely
\end{tabular} & $\begin{array}{c}\text { co drugi } \\
\text { sezon } \\
\text { every other } \\
\text { season }\end{array}$ & \begin{tabular}{|c} 
raz \\
w sezonie \\
once per \\
season
\end{tabular} & \begin{tabular}{|c|} 
kilka razy \\
w sezonie \\
several \\
times per \\
season
\end{tabular} & $\begin{array}{l}\text { wartość } \\
\text { value }\end{array}$ & \begin{tabular}{|l} 
istotność \\
asymptotyczna \\
(dwustronna) \\
asymp. Sig \\
2-sided
\end{tabular} \\
\hline $\begin{array}{l}\text { Wracam, bo lubię to miejsce } \\
\text { I come back because I like } \\
\text { this place }\end{array}$ & 4 & 38 & 70 & 59 & 59 & \multirow{8}{*}{189,563} & \multirow{8}{*}{0,000} \\
\hline $\begin{array}{l}\text { Dobre warunki narciarskie } \\
\text { Good ski conditions }\end{array}$ & 3 & 7 & 13 & 6 & 12 & & \\
\hline $\begin{array}{l}\text { Przyjaciele mnie zachęcili } \\
\text { My friends encouraged me } \\
\text { to come here }\end{array}$ & 31 & 18 & 4 & 8 & 2 & & \\
\hline $\begin{array}{l}\text { Sława, renoma tego miejsca } \\
\text { Fame, popularity of this place }\end{array}$ & 14 & 13 & 0 & 8 & 6 & & \\
\hline $\begin{array}{l}\text { Chęć spróbowania swoich sił } \\
\text { I wanted to try my skills here }\end{array}$ & 32 & 9 & 9 & 0 & 0 & & \\
\hline Inne / Others & 12 & 13 & 4 & 16 & 18 & & \\
\hline $\begin{array}{l}\text { Brak odpowiedzi } \\
\text { Lack of an answer }\end{array}$ & 4 & 2 & 0 & 2 & 3 & & \\
\hline Razem / Total & 100 & 100 & 100 & 100 & 100 & & \\
\hline
\end{tabular}

Źródto: na podstawie Hibner 2018.

Source: based on Hibner 2018.

zachęcony przez przyjaciół. W tej grupie zanotowano również największy odsetek osób, które wybrały wskazane ośrodki narciarskie ze względu na ich renomę lub też z potrzeby sprawdzenia swoich sił czy umiejętności (tab. 14). Częstotliwość przyjazdów również istotnie wpływa na czynnik, dla którego wybrano badane ośrodki narciarskie. Zaobserwowano, iż czynnik sentymentalny (,wracam, bo lubię to miejsce”) jest najważniejszy wśród respondentów przyjeżdżających regularnie. Natomiast respondenci, którzy przyjechali na obszary badane po raz pierwszy, kierowali się przede wszystkim zachętą ze strony przyjaciół (31\%), jak również potrzebą sprawdzenia swoich sił w tych konkretnych ośrodkach (32\%; tab. 15). 


\section{Dyskusja i wnioski}

Hall (2003, za: Mika 2014) zauważył w swojej pracy, iż wcześniejsze doświadczenia turystyczne wpływają znacząco na przyszłe wybory turystów dotyczące miejsca czy formy wypoczynku. Co więcej, Pearce i Lee (2005) również zaobserwowali w swoich badaniach istotny wpływ wcześniejszych doświadczeń turystycznych na motywacje turystyczne. Podobne zależności zaobserwowano w uzyskanych wynikach badań. Wynika z nich, że wcześniejsze doświadczenia górskie istotnie wpływają na czynniki motywacyjne, zarówno typu push, jak i typu pull.

Doświadczenie w aspekcie emocjonalnym, rozumiane jako potrzeba przeżycia niezapomnianych wrażeń, przygód czy „dreszczyku” emocji związanych z uprawianiem narciarstwa (por. motywy według Zdebskiego i Winiarskiego, za: Zdebski 1979, 2010), znalazło odzwierciedlenie w ogólnych motywacjach respondentów z obu ośrodków. Do podobnych zależności nawiązywała w swojej pracy m.in. Niezgoda (2013a). W części dotyczącej metodyki badań wspomniano, iż respondentom zaproponowano 22 czynniki motywacyjne do wyboru, wśród których dużą grupę stanowiły czynniki związane z doświadczeniem w aspekcie: (1) emocjonalnym, które zaklasyfikowano do kategorii motywów ambicyjnych: potrzeba sprawdzenia swoich sił, przeżycia przygody, „dreszczyku” emocji, potrzeba zaimponowania bliskim, wyzwanie; (2) sentymentalnym - wspomnienia, które zaklasyfikowano do kategorii motywów sentymentalnych; (3) poznawczym, które zaklasyfikowano do kategorii motywów poznawczych: ciekawość, poznanie nowych miejsc. Najistotniejszą grupę - 8\% - stanowiły wśród nich motywy ambicyjne, szczególnie wśród osób bardzo młodych, przyjeżdżających średnio co drugi sezon do obu ośrodków narciarskich. Prawdopodobnie z uwagi na młody wiek respondentów cechujących się takimi motywacjami były to osoby posiadające jednocześnie mniej bogate wczéniejsze doświadczenia górskie. Z badań Olszewskiej (2018) wynika, iż przyczyny o charakterze ambicyjnym stanowiły najistotniejszy czynnik motywujący do uprawiania ekstremalnych form sportu i turystyki. Istotny w badaniach Olszewskiej był ponadto motyw poznawczy związany z ciekawością (ok. 16\%). W niniejszych badaniach motyw poznawczy został wskazany jedynie przez $2 \%$ respondentów.

Do celów niniejszych badań czynniki motywacyjne podzielono na dwie kategorie, zgodnie z koncepcją Danna (1977) (Crompton, McKay 1997), dzieląc je na czynniki typu push - skłaniające ludzi do podjęcia aktywności turystycznej (rys. 4) - oraz czynniki typu pull - przyciągające turystów do konkretnych ośrodków (rys. 5). W pracy odnotowano także, iż czynniki motywacyjne zarówno typu push, jak i typu pull są od siebie zależne oraz wpływają na inne zmienne. Zdaniem autorki czynniki typu push mają bardziej ogólny charakter, przez co słabiej odzwierciedlają różnice między ankietowanymi. Natomiast czynniki typu pull zdecydowanie lepiej oddają różnice między respondentami. 
$Z$ analizy doświadczenia narciarskiego ankietowanych wynika, że Kasprowy Wierch jest odwiedzany głównie przez turystów posiadających bogatsze doświadczenia narciarskie, nabyte podczas pobytu w innych, zagranicznych ośrodkach narciarskich. Może to wynikać z faktu, iż Kasprowy Wierch jest jedynym tak wysoko położonym ośrodkiem narciarskim w Polsce. Można przypuszczać, iż jego lokalizacja w „sercu” Tatr, na wysokości 1987 m n.p.m., daje możliwość skorzystania z nielicznych, ale za to długich i trudniejszych tras zjazdowych, co bardziej odpowiada respondentom, którzy doskonalili już swoje umiejętności w innych ośrodkach.

Ciekawą zależność odnotowano również między częstotliwością przyjazdów a wcześniejszymi doświadczeniami narciarskimi. Obydwa badane ośrodki: Kasprowy Wierch i Tatrzańska Łomnica, a zwłaszcza ten pierwszy, posiadają znacznie uboższą ofertę (liczba tras, wyciągów, ogólne przygotowanie ośrodka itp.) w stosunku do bardziej rozbudowanych ośrodków zagranicznych, np. alpejskich (Ośrodki narciarskie 2020). Według autorki osoby posiadające bogatsze przeszłe doświadczenia narciarskie mogą rzadziej wybierać lokalne ośrodki z uboższą infrastrukturą z uwagi na przyzwyczajenie do innych standardów.

Z badań wynika, że wcześniejsze doświadczenia górskie respondentów wpływają na wiele innych zmiennych, przede wszystkim na te dotyczące motywacji. Być może wynika to z faktu, iż zmienna wcześniejsze doświadczenia górskie stanowi w niniejszej pracy sumę różnorodnych górskich aktywności uprawianych do tej pory przez respondentów w różnych obszarach górskich. Jest przez to pojęciem znacznie szerszym aniżeli zmienna wcześniejsze doświadczenia narciarskie, która koncentruje się wyłącznie na jednej z form turystyki i związanych z nią motywacjach. Doświadczenia narciarskie są niejako pochodną doświadczeń górskich i, jak wynika z badań, są od nich zależne.

\section{Literatura}

Andersson T.D., 2007, The Tourist in the Experience Economy, Scandinavian Journal of Hospitality and Tourism, 7 (1), 46-58.

Babbie E., 2003, Badania spoteczne w praktyce, Wydawnictwo PWN, 1-659.

Bansal H., Eiselt H.A., 2004, Exploratory research of tourist motivations and planning, Tourism Management, 25, 387-396.

Cessford G., Muhar A., 2003, Monitoring options for visitor numbers in national parks and natural areas, Journal for Nature Conservation, 11 (4), 240-250.

Cohen E., 1979, Rethinking the sociology of tourism, Annals of Tourism Research (Jan/Mar), 18-35.

Crompton J.L., McKay S.L., 1997, Motives of visitors attending festival events, Annals of Tourism Research, 24 (2), 425-439.

Dziewanowska K., Kacprzak A., 2016, Dziatania z zakresu marketingu doświadczen w oczach polskich konsumentów - wyniki badań jakościowych, Studia Ekonomiczne. Zeszyty Naukowe Uniwersytetu Ekonomicznego w Katowicach, 255, 18-27. 
Eagles P.F.J., McCool S.F., Haynes C.D.A., 2002, Sustainable Tourism in Protected Areas: Guidlines for Planning and Management, IUCNxv, Gland Switzerland, Cambridge UK, 1-183.

Faracik R., 2011, Potrzeby i motywacje turystyczne, [w:] W. Kurek (red.), Turystyka, Wydawnictwo PWN, Warszawa, 122-141.

Fodness D., 1994, Measuring tourist motivation, Annals of Tourism Research, 21 (3), 555-581.

Gnoth J., 1997, Tourism motivation and expectation formation, Annals of Tourism Research, 24 (2), 283-304.

Hibner J., 2018, Wptyw kolei linowych na strukture ruchu turystycænego w Tatrach, maszynopis pracy doktorskiej, IGiGP UJ, niepublikowana, 1-256.

Kasprowy Wierch trasy narciarskie 2019, http://www.pkl.pl/kasprowy-wierch/trasy-narciarskie. html, (dostęp: 20.12.2019).

Konu, H., Kajala L., 2012, Segmenting Protected Area Visitors Based on Their Motivations, Nature Protection Publications of Metsähallitus, Series A, 194, 1-74.

Kozioł L., 2012a, Trójczynnikowa koncepcja motywacji turystycznej, Ekonomiczne Problemy Usług, 84, 43-52.

Kozioł L., 2012b, Typologia czynników motywujqcych do podróżowania, Zeszyty Naukowe Małopolskiej Wyższej Szkoły Ekonomicznej w Tarnowie, 20 (1), 87-98.

Krzesiwo K., 2015, Rozwój turystyki narciarskiej w świetle idei zrównoważonego rozwoju - stan badań, Prace Geograficzne, zeszyt 141, IGiGP UJ, Kraków, 117-140.

Kurek W., 2004, Turystyka na obszarach górskich Europy. Wybrane sagadnienia, Wydawnictwo IGiGP UJ, Kraków, 1-214.

Kurek W., (red.), 2011, Turystyka, Wydawnictwo PWN, Warszawa, 1-544.

Larsen S., 2007, Aspects of a Psychology of the Tourist Experience, Scandinavian Journal of Hospitality and Tourism, 7 (1), 7-18.

Laszczyk A.J., Wójcik M., Rokita T., 2007, Modernizacja napowietrznej kolei linowej „Kasprowy Wierch” w Zakopanem, Transport Miejski i Regionalny, 12, 26-30.

Merriam-Webster 2020, https://www.merriam-webster.com/dictionary/experience (dostęp: 16.03.2020).

Mika M., 2014, Zatośenia i determinanty podtrzymywalności lokalnego rozwoju turystyki, Wydawnictwo IGiGP UJ, Kraków, 1-233.

Mossberg L., 2007, A Marketing Approach to the Tourist Experience, Scandinavian Journal of Hospitality and Tourism, 7 (1), 59-74.

Neuhofer B., Buhalis D., Ladkin A., 2012, Conceptualising technology enhanced destination experiences, Journal of Destination Marketing \& Management, 1, 36-46.

Niezgoda A., 2013a, Turystyka doświadczeń - dawna czy nowa forma turystyki?, [w:] R. Wiluś, J. Wojciechowska (red.), Warsztaty a geografii turyzmu, 3, Wydawnictwo Uniwersytetu Łódzkiego, 37-47.

Niezgoda A., 2013b, Rola doswiadczenia w zachowaniach konsumenta na rynku turystycznym. Koncepcja ekonomii doświadcæeń i marketingu doznań, Folia Turistica, 28, 91-106.

Nowacki M., Kruczek Z., 2019, Wspóttworzenie doświadczeń, emocje a zadowolenie i intencje osób zwiedzajqcych atrakcje turystyczne, Przedsiębiorczość i Zarządzanie, XX, 2 (1), 31-42. 
Oh H., Fiore A.M., Jeoung M., 2007, Measuring Experience Economy Concepts: Tourism Applications, Journal of Travel Research, 46, 119-132.

Olszewska B., 2018, Motywacje osób uprawiajacych ekstremalne formy sportu i turystyki, Zeszyty Naukowe Uczelni Vistula, 60 (3), 18-44.

Ośrodki narciarskie 2020, https://www.skiinfo.pl/, (dostęp: 26.06.2020).

Pearce P.L., Lee U.-I., 2005, Developing the Travel Career Approach to Tourist Motivation, Journal of Travel Research, 43, 226-237.

Pine B.J., Gilmore J.H., 1998, Welcome to the Experience Economy, Harvard Business Review, $97-105$.

PKL kolejki 2019, http://www.pkl.pl/kasprowy-wierch/koleje-i-wyciagi.html, (dostęp: 21.12.2019).

Przecławski K., 1996, Ciłowiek a turystyka. Zarys socjologii turystyki, Albis, Kraków, 1-160.

Quan S., Wang N., 2003, Towards a structural model of the tourist experience: an illustration from food experiences in tourism, Tourism Management, 25, 297-305.

Quinlan Cutler S., Carmichael B., 2010, The dimensions of the tourist experience, [w:] M. Morgan, P. Lugosi, B. Ritchie (red.), The Tourism and Leisure Experience: Consumer and Managerial Perspectives, Channel View Publications, Bristol, 3-26.

Skawiński P., 2005, Ochrona i udostępnianie Tatræańskiego Parku Narodowego; stan obecny i wizja przysztosci, [w:] Z. Krzan (red.), Przyroda Tatrzańskiego Parku Narodowego a cztowiek. Tatrzański Park Narodowy na tle innych górskich terenów chronionych, 3, TPN, Polskie Towarzystwo Przyjaciół Nauk o Ziemi, Zakopane, 25-28.

Snepenger D., King J., Marshall E., Uysal M., 2006, Modeling Iso-Ahola's Motivation Theory in the Tourism Context, Journal of Travel Research, 45, 140-149.

Stankey G., 1973, Visitor perception of wilderness recreation carrying capacity, USDA Forest Service Research paper INT-142 1973, Intermountain Forest and Range Experiment Station, Ogden, Utah, 1-61.

Stasiak A., 2013, Produkt turystyczny w gospodarce doświadczeń, Turyzm, 1, 29-38.

Stasiak A., 2015, Triada doświadczen turystycznych i efekt „wow!” podstawq kreowania nowoczesnej oferty turystycænej, Prace Naukowe Uniwersytetu Ekonomicznego we Wrocławiu, 379, 332-347.

Stasiak A., 2016, Doświadczenie - stary-nowy paradygmat turystyki, Folia Turistica, 41, 191-16. TANAP 2019, https://www.tanap.org/navstevny-poriadok/, (dostęp: 21.12.2019).

TPN 2019, https://tpn.pl/poznaj, (dostęp: 21.12.2019).

TPN statystyki 2019, https://tpn.pl/zwiedzaj/turystyka/statystyka, (dostęp: 1.12.2019).

Uriely N., 2005, The Tourist Experience Conceptual Developments, Annals of Tourism Research, 32, 1, 199-216.

Walls A.R., Okumus F., Wang Y.R., Joon-Wuk Kwun D., 2011, An epistemologicalview of consumer experiences, International Journal of Hospitality Management, 30, 10-21.

Wickens E., 2002, The sacred and the profane. A tourist Typology, Annals of Tourism Research, $29,3,834-851$.

Vysoke Tatry kolejki 2019, https://www.vt.sk/aktualny-stav-lanoviek-a-zjazdoviek/, (dostęp: 20.12.2019). 
Vysoke Tatry trasy narciarskie 2019, https://www.vt.sk/hory/lyzovacka/mapy/ (dostęp: 20.12.2019). Zdebski J., 1979, Motywacja do uprawiania turystyki górskiej, [w:] Spoteczne problemy cæasu wolnego, Wydawnictwo Naukowe Uniwersytetu Warszawskiego, Warszawa.

Zdebski J., 2010, Rekreacyjne walory narciarstwa biegowego, [w:] Sz. Krasicki (red.), Studia i Monografie. Narciarstwo Biegowe, 63, Wydawnictwo AWF, 63-83.

\author{
Joanna Hibner \\ Instytut Geografii i Gospodarki Przestrzennej UJ \\ Zaktad Gospodarki Turystycznej i Uzdrowiskowej \\ ul. Gronostajowa 7, 30-387 Kraków \\ joanna.hibner@uj.edu.pl
}

